\title{
Design, Synthesis and Characterization of Novel sn-1 Heterocyclic DAG- lactones as PKC e Activators
}

Eleonora Elhalem, ${ }^{\$ \neq}$ Ana Bellomo, ${ }^{\$ \neq}$ Mariana Cooke, ${ }^{, \#}$ Antonella Scravaglieri, ${ }^{\S}$ Larry V. Pearce, ${ }^{f}$ Megan L. Peach, ${ }^{\perp}$ Lucia Gandolfi Donadio, ${ }^{\xi \neq}{ }^{\star}$ Marcelo G. Kazanietz, ${ }^{\dagger *}$ María J. $\operatorname{Comin}^{\xi * *}$

* Co-corresponding authors

$\S$ Departamento de Ingredientes Activos y Biorrefinerías, Instituto Nacional de Tecnología Industrial, Av. General Paz 5445, B1650WAB, San Martín, Buenos Aires,Argentina

\$ Consejo Nacional de Investigaciones Científicas y Técnicas (CONICET), Av. General Paz 5445, B1650WAB San Martín, Buenos Aires, Argentina

$\dagger$ Department of Systems Pharmacology and Translational Therapeutics, Perelman School of Medicine, University of Pennsylvania, Philadelphia, PA 19104, USA

\# Department of Medicine, Einstein Medical Center Philadelphia, Philadelphia, PA 19141, USA

${ }^{f}$ Laboratory of Cancer Biology and Genetics, Center for Cancer Research, National Cancer Institute, NIH, Bethesda, Maryland 20892-4255, USA

${ }^{\perp}$ Basic Science Program, Chemical Biology Laboratory, Frederick National Laboratory for Cancer Research, National Institutes of Health, Frederick, MD 21702, USA 


\section{ABSTRACT}

Protein kinase $\mathrm{C}(\mathrm{PKC})$ isozymes are the best studied members of the family of diacylglycerol (DAG)-regulated proteins containing $\mathrm{C} 1$ domains and depict an attractive drug target for the treatment of several diseases. DAG-lactones proved to be useful templates for the design of potent and selective $\mathrm{C} 1$ domain ligands. The ester moiety at $s n-1$ position, a common feature in this template, is relevant for interaction with the $\mathrm{PKC} \mathrm{C1}$ domains; although it represents a labile group susceptible to endogenous esterases. Thus, an interesting challenge was to replace the ester group of these ligands while still maintaining the biological activity. In this study, we present the synthesis and functional characterization of novel diacylglycerol-lactones containing heterocyclic ring substituents (1-6) at $s n-1$ position. Our results showed that DAG-lactone 2 (10B12) with an isoxazole ring, has the capacity to bind $\mathrm{PKC} \alpha$ and $\mathrm{PKC} \varepsilon$ with nanomolar affinity (PKC $\alpha: \mathrm{Ki}=79.3 \mathrm{nM}$; $\mathrm{PKC} \varepsilon: \mathrm{Ki}=33.6 \mathrm{nM}$ ) showing a moderate selectivity for $\mathrm{PKC} \varepsilon$ relative to PKC $\alpha$. Remarkably, the pattern of PKC isozyme translocation in intact cells revealed marked preferential selectivity for $\mathrm{PKC} \varepsilon$ relative to $\mathrm{PKC} \alpha$ for this DAG-lactone. 10B12 induced a prominent reorganization of the actin cytoskeleton into peripheral ruffles in lung cancer cells, a response specifically mediated by $\mathrm{PKC} \varepsilon$, as confirmed by $\mathrm{PKC} \varepsilon$ RNA interference (RNAi) silencing. From this study, introducing a stable isoxazole ring as an ester surrogate in DAGlactones emerges as a novel structural approach to achieve PKC isozyme selectivity. 


\section{INTRODUCTION}

Protein kinase $\mathrm{C}(\mathrm{PKC})$ isozymes comprise a family of signaling proteins that play essential roles in the control of cellular functions as diverse as cell cycle progression, differentiation, apoptosis, proliferation, motility and gene expression. ${ }^{1}$ The central role of $\mathrm{PKC}$ in cellular signal transduction has established it as a validated therapeutic target for various pathologies such as cancer, diabetes, Alzheimer's and cardiovascular diseases. ${ }^{2-5}$

All the members of the PKC family contain in their $N$-terminal regulatory domain one or two copies of $\mathrm{C} 1$ domains, a zinc binding, cysteine-rich motif of 50-51 amino acid residues. In classical/conventional (cPKCs: $\alpha, \beta 1, \beta 2$ and $\gamma$ ) and novel isoforms (nPKCs: $\delta, \varepsilon, \eta$ and $\theta$ ), the second messenger diacylglycerol (DAG) binds to the $\mathrm{C} 1 \mathrm{a}$ and $\mathrm{C} 1 \mathrm{~b}$ domain present in their regulatory region, which promotes their translocation to the plasma membrane or other intracellular compartments and subsequent enzyme activation. The $\mathrm{C} 1$ domains in cPKCs and nPKCs are also high affinity binding sites for the phorbol ester tumor promoters, natural compounds that bind to the same site as DAG. Unlike the $\mathrm{C} 1$ domains in $\mathrm{cPKCs}$ and $\mathrm{nPKCs}$, a single $\mathrm{C} 1$ domain present in atypical isoforms (aPKCs: $\zeta$ and $\mathrm{t} / \lambda$ ) is unable to bind either phorbol esters or DAG. ${ }^{6}$ Although PKCs are the best studied class of signaling proteins with $\mathrm{C} 1$ domains, ${ }^{7}$ other families of proteins containing DAG/phorbol ester-responsive $\mathrm{C} 1$ domains have been later identified. These include RasGRPs, which are guanyl exchange factors for Ras; chimaerins, which are GTPase activating proteins for Rac; DAG kinases (DGKs), enzymes responsible for DAG phosphorylation and the generation of phosphatidic acid; MRCK (myotonic dystrophy kinase-related cdc42-binding kinase), protein kinase D isoforms (PKDs) and Munc-13 isoforms. ${ }^{8,9}$ Despite the overall similar structure of $\mathrm{C} 1$ domains in these proteins, subtle 
differences may confer differential ligand binding and membrane association properties to individual members of the family, thus encouraging the generation of agents capable of displaying binding selectivity among the different phorbol ester receptors and specificity for activation.

Among the multiple $\mathrm{C} 1$ domain ligands generated as agents capable of activating PKC isozymes, diacylglycerol lactones (DAG-lactones) represent a unique class of DAG mimetics in which the flexibility of the structure has been constrained to reduce the entropic loss due to binding. Indeed, the natural second messenger DAG displays rather weak affinity for cPKCs and nPKCs, largely reflecting the flexibility of the glycerol backbone, with the consequence that the immobilization of the glycerol upon binding is entropically unfavorable. The design of DAGlactones, pioneered by the Marquez and Blumberg laboratories, constitutes the largest synthetic efforts to-date leading to the development of potent $\mathrm{C} 1$ domain ligands in which the glycerol backbone of DAG has been cyclized, leading to a rigid structure that eliminates the entropic penalty. Through appropriate manipulation of the hydrophobic side chains, it has been possible to obtain DAG-lactone analogues displaying higher affinity than the natural DAGs, and in many cases achieving nanomolar binding affinities similar to those of phorbol esters or related compounds derived from natural sources. ${ }^{10-12}$

Modeling and docking experiments have revealed two different modes of binding for diacylglycerol itself and the DAG-lactones, defined by the interaction between the $\mathrm{C} 1$ domain and either the $s n-1$ carbonyl or the $s n-2$ carbonyl in the DAG-lactone structure (Figure 1$).{ }^{13}$ These two comparable binding modes form identical networks of hydrogen bonds with receptor amino acids Thr 12, Leu21, and Gly23, as is observed in the crystal structure of PKC $\delta$ Clb with 
phorbol 13-O-acetate. ${ }^{14}$ For convenience in comparing $\mathrm{C} 1$ domains from different isozymes we use residue numbering internal to the $\mathrm{C} 1$ domain, with residue 1 corresponding to the first zincbinding histidine, and residue 50 corresponding to the last zinc-binding cysteine.
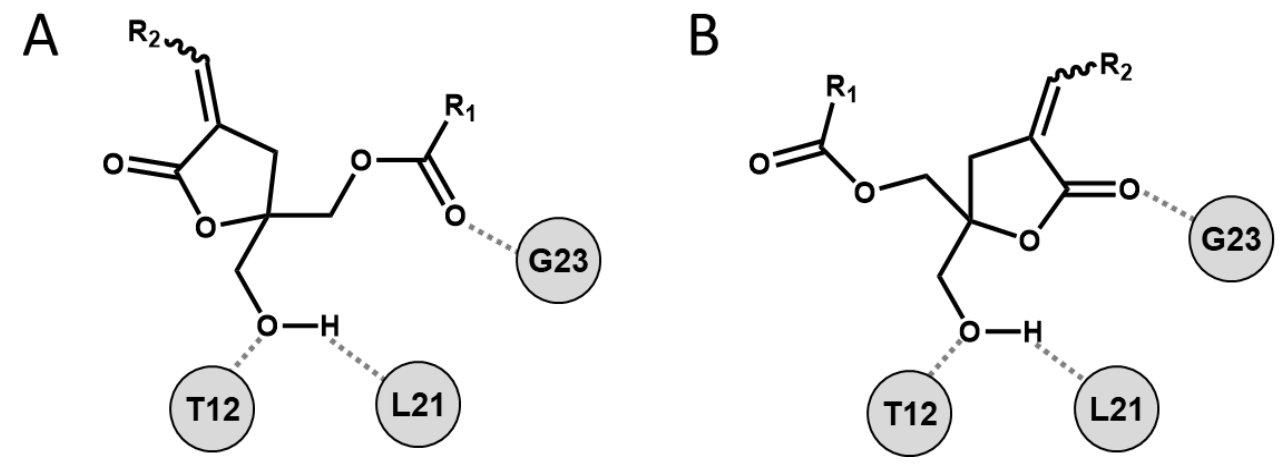

Figure 1. Schematic illustration of the $\mathrm{C} 1$ domain hydrogen bonding interactions in the alternative sn-1 (A) and sn-2 (B) binding modes for DAG-lactones.

The carbonyl that is not directly involved in $\mathrm{C} 1$ domain binding contributes to the binding energy through interactions with the $\mathrm{C} 1$ domain surface and the lipid bilayer in the $\mathrm{C} 1$ domainligand-membrane ternary complex. Thus, both carbonyl groups have been shown to be essential for a strong interaction with PKC. The distinct patterns of acyl (R1) and alkyl (R2) substitution are key elements that determine selectivity providing significant differences in biological outcome patterns. Applying this approach, combinatorial libraries of DAG-lactones were produced, leading to compounds with marked selectivity for the RasGRP family relative to their affinity for PKC $\alpha$ and other PKC isozymes. ${ }^{11,12,15}$ Recent studies described the characterization of AJH-836, one of the most potent DAG-lactone known to date. This compound exhibits pronounced selectivity in vitro for novel PKC $\varepsilon$ and $\mathrm{PKC} \delta$ relative to classical PKC $\alpha$ and $\mathrm{PKC} \beta$. Remarkably, AJH-836 displayed significant selectivity for the translocation of PKCE to plasma 
membrane (a readout of activation) relative to $\mathrm{PKC} \alpha$. This selectivity could be also observed at a functional level in cellular models. For example, AJH-836 is capable of inducing major changes in the reorganization of the actin cytoskeleton, specifically inducing the formation of peripheral membrane ruffles, a response that is mediated primarily by $\mathrm{PKC} \varepsilon .{ }^{16}$ On the other hand, AJH-836 has limited ability to induce transcriptional activation of genes in lung cancer cells, a response that is mainly mediated by $\mathrm{PKC} \alpha^{17}$, ultimately reflecting its selectivity for the $\mathrm{nPKCs}$ relative to cPKCs.

A fundamental feature common to DAG-lactones is the presence of an ester moiety at $s n-1$ position that, as discussed above, is important in mediating membrane and receptor interactions; however, this makes the DAG-lactones susceptible to hydrolysis by endogenous esterases, reducing their stability in cells. ${ }^{18}$ Previous attempts to replace this labile functional group led to a significant loss in biological activity. Interestingly, the isosteric replacement of the side chain ester group at the $s n-1$ position with an amide or an $N$-hydroxyl amide group, developed by Marquez and colleagues, revealed a dramatic drop in binding affinity of more than 3 orders of magnitude, suggesting that the new functional groups were not able to adequately recapitulate the polar interactions that the sn- 1 carbonyl makes in the $\mathrm{C} 1$ domain membrane-DAG-lactone ternary complex. ${ }^{18,19}$ In the present study, we designed and synthesized heterocycle-containing DAG-lactones in order to expand the chemical space covered by these ligands, leading to the development of novel activators of DAG-responsive $\mathrm{C} 1$ domain containing proteins. Using AJH-836 as a lead DAG-lactone structure, we synthesized six new compounds in which we varied the nature of the heterocyclic ring at thesn-1 position, specifically replacing the ester moiety with isoxazole (1-2), triazole (3-4) and tetrazole (5-6) groups (Fig. 2). Evaluation of their 
binding and functional properties in cellular models revealed that a stable isoxazole ring can function as an ester surrogate to allow binding to the $\mathrm{C} 1$ domain.

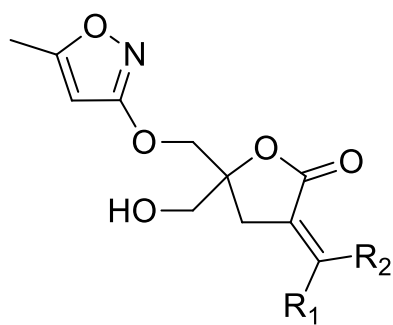

1: $\mathrm{R}_{1}, \mathrm{R}_{2}=\mathrm{CH}_{3}$

2: $R_{1}=$

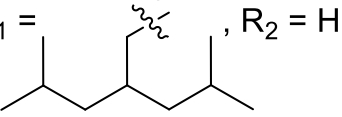

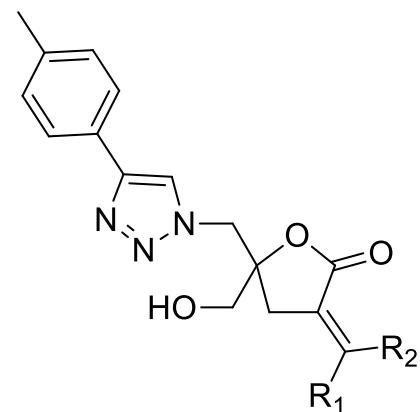

3: $\mathrm{R}_{1}, \mathrm{R}_{2}=\mathrm{CH}_{3}$

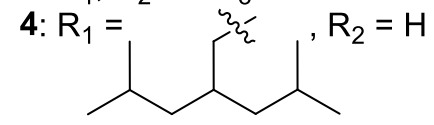

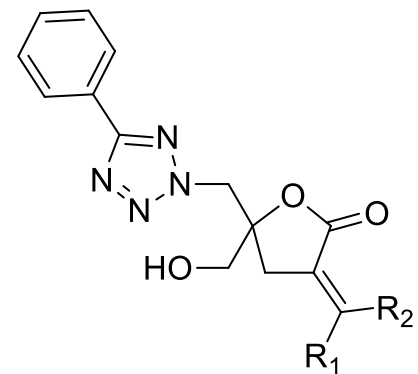

5: $\mathrm{R}_{1}, \mathrm{R}_{2}=\mathrm{CH}_{3}$

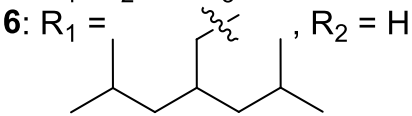

Figure 2. Structure of new heterocyclic DAG-lactones 1-6.

\section{RESULTS AND DISCUSSION}

\section{Design of the compounds}

Isoxazole is an azole with an oxygen atom attached to nitrogen often found in natural products and in various pharmaceutical and therapeutic products such as insecticides, antibacterials, antibiotics, antifungals, among others. It is interesting to obtain the isoxazolol derivative since this group represents a bioisostere of the ester group present in our lead structure at $s n-1$ position..$^{20,21}$

The 1,2,3-triazole unit is a fundamental building block found in different bioactive compounds. One of the most interesting features of triazoles is their ability to mimic the characteristics of different functional groups. This aromatic heterocycle is stable to metabolic 
and chemical degradation and is capable of acting as a hydrogen bond donor and acceptor, which can be convenient in binding of biomolecular targets. This explains its wide use as a bioisostere for the synthesis of new active molecules, mainly amide bonds, although there are also some examples where it is used as an ester group isostere, to reduce the susceptibility to enzymatic degradation in vivo. ${ }^{22}$

Tetrazole is a five-member, planar, heterocycle with four nitrogen atoms arranged in a regular fashion rarely present in nature. It has attracted significant attention, especially in medicinal chemistry, because it increases drug bioavailability and is resistant to biological degradation, extending their action. ${ }^{23,24}$

\section{Molecular modeling}

We performed docking experiments to analyse the interactions formed by the new heterocyclic rings and the $\mathrm{C} 1$ domain, using the crystal structure of $\mathrm{PKC} \delta \mathrm{C} 1 \mathrm{~b}$ domain bound to phorbol ester as the receptor structure. This domain has $62 \%$ sequence identity with the PKC $\alpha$ and $\mathrm{PKC} \varepsilon \mathrm{C} 1 \mathrm{~b}$ domains, and ligand binding residues are strictly conserved.

Docking predicted that the isoxazole containing compounds, which retain an ether oxygen in the linkage between the heterocycle and the lactone ring, are capable of binding in both sn- 1 and sn-2 orientations, like the parent DAG-lactone structures (Figure 3A,B). The triazole and tetrazole DAG-lactones, with a single methylene spacer between the two rings, bind exclusively sn-1 (Figure 3C, D). These compounds cannot bind sn-2 because the shorter linker does not give enough space to the heterocyclic ring and instead of extending out of the back of the binding slot it bumps against a side loop without making any productive interactions. 


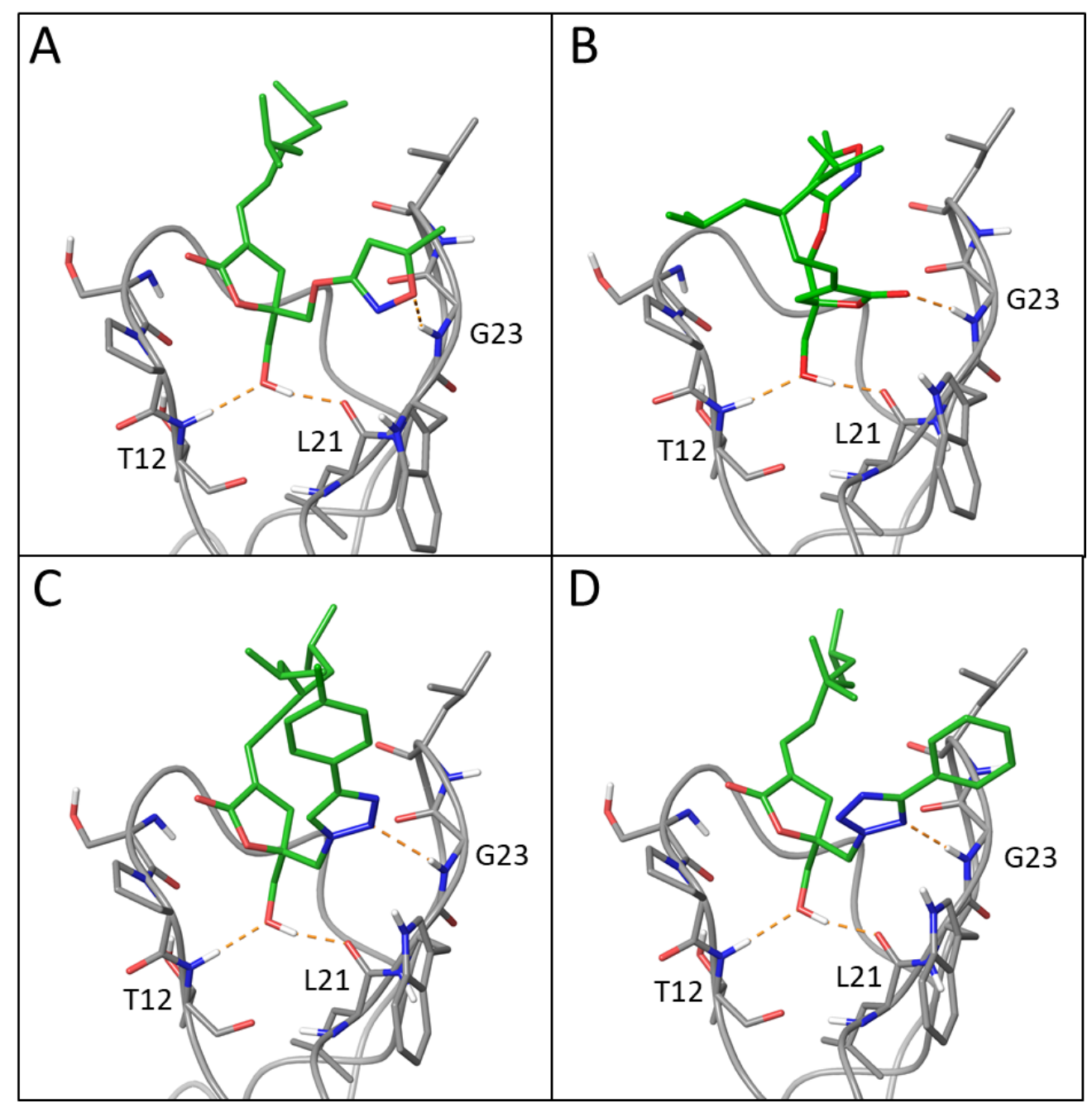

Figure 3. Docked structures of compound 2 in sn-1 orientation (A), and sn-2 orientation (B), and compounds 4 (C), and 6 (D) in sn-1 orientation. Hydrogen bonds are indicated with dashed orange lines.

In the sn-1 orientation the hydrogen bonding interaction between the $\mathrm{C} 1$ domain backbone at Gly23 and the DAG-lactone is stronger in the tri- and tetrazole compounds because with the shorter linker the ring can adopt an orientation such that the hydrogen bond is in the plane of the ring. With the additional ether oxygen in the linker, in the isoxazole compounds, the NH donor is not aligned with the ring plane and the hydrogen bonding is a weaker, out-of-plane interaction with isoxazole oxygen atom. ${ }^{25}$ 


\section{Chemistry}

We started the synthesis of new analogues with orthogonally protected lactone $\mathbf{7}$ bearing a benzyl and a silyl ether group. ${ }^{26}$ In order to explore the chemical compatibility between reaction conditions required to build the heterocycles and for hydroxyl group deprotection we decided to synthesize simple derivatives bearing a propan-2-ylidene group at $s n-2$ position. This alkyl substituent was introduced through a well-established procedure using an alkylation-elimination sequence to give lactone $\mathbf{8}$ according to published methods (Scheme1). ${ }^{13,27}$

Scheme 1: Synthesis of isoxazole (1) and triazole (3-4) derivatives employing orthogonally protected lactones
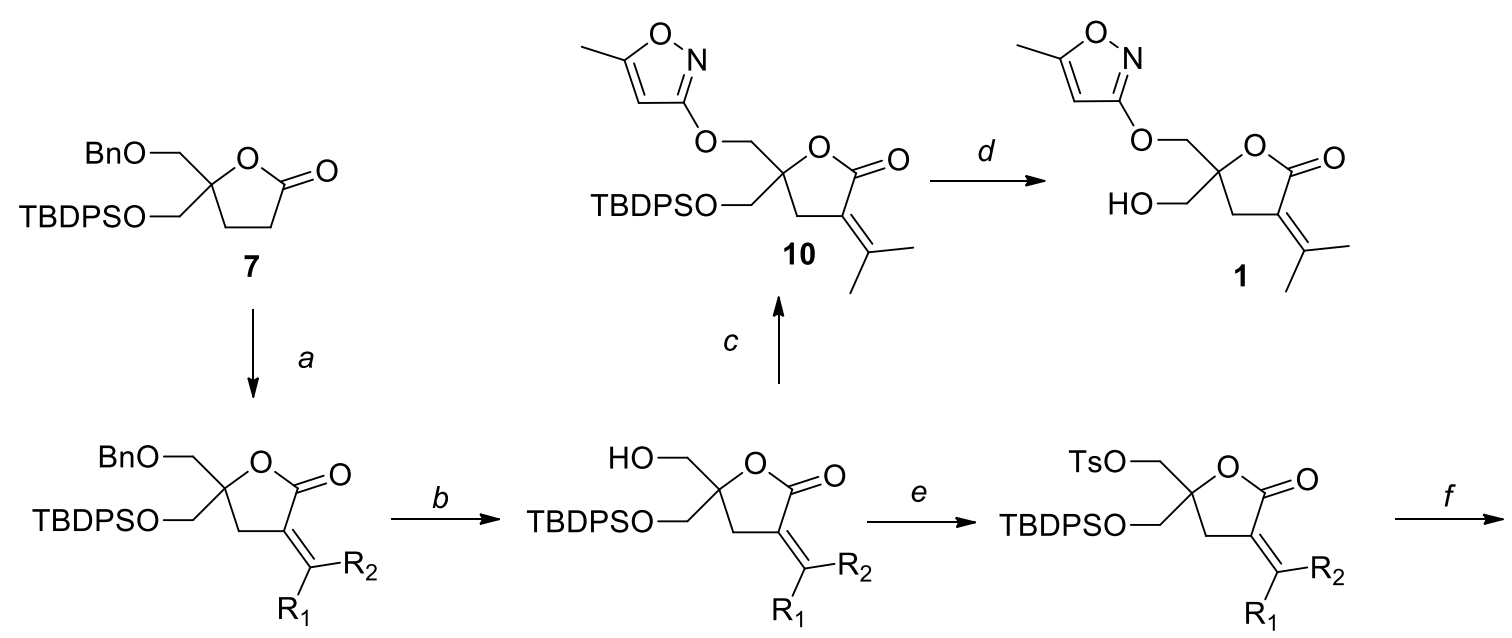

8: $\mathrm{R}_{1} \mathrm{R}_{2}=\mathrm{CH}_{3}$
14: $\mathrm{R}_{1}=\mathrm{CH}_{2} \mathrm{CH}\left(\mathrm{CH}_{2}(\mathrm{PPr})\right)_{2}, \mathrm{R}_{2}=\mathrm{H}$

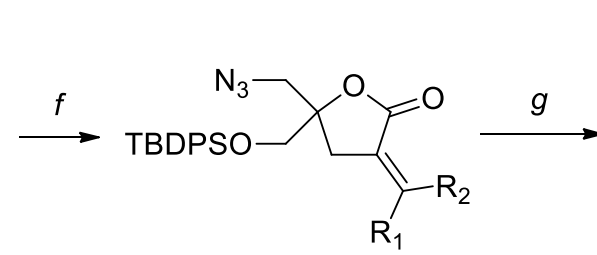

12: $\mathrm{R}_{1}, \mathrm{R}_{2}=\mathrm{CH}_{3}$

17: $\mathrm{R}_{1}=\mathrm{CH}_{2} \mathrm{CH}\left(\mathrm{CH}_{2}(\mathrm{iPr})\right)_{2}, \mathrm{R}_{2}=\mathrm{H}$
9: $\mathrm{R}_{1}, \mathrm{R}_{2}=\mathrm{CH}_{3}$

15: $\mathrm{R}_{1}=\mathrm{CH}_{2} \mathrm{CH}\left(\mathrm{CH}_{2}(\mathrm{PPr})\right)_{2}, \mathrm{R}_{2}=\mathrm{H}$
11: $\mathrm{R}_{1}, \mathrm{R}_{2}=\mathrm{CH}_{3}$

16: $\mathrm{R}_{1}=\mathrm{CH}_{2} \mathrm{CH}\left(\mathrm{CH}_{2}(\mathrm{PPr})\right)_{2}, \mathrm{R}_{2}=\mathrm{H}$

Reagents and conditions: (a) 1. $\mathrm{R}_{1} \mathrm{R}_{2} \mathrm{CO}$, LiHMDS, THF, $-78{ }^{\circ} \mathrm{C}, 2-4 \mathrm{~h}$; 2.(i) $\mathrm{CH}_{3} \mathrm{SO}_{2} \mathrm{Cl}, \mathrm{Et}_{3} \mathrm{~N}, 0{ }^{\circ} \mathrm{C}$, $5 \mathrm{~h}$; (ii) DBU, $\mathrm{CH}_{2} \mathrm{Cl}_{2}$, room temp, $24 \mathrm{~h}, 62 \%$ for $\mathbf{8}, 35 \%$ for $14(E / Z$ regioisomers $69 \%)$; (b) $\mathrm{BCl}_{3}$, 
$\mathrm{CH}_{2} \mathrm{Cl}_{2},-78{ }^{\circ} \mathrm{C}, 2 \mathrm{~h}, 97 \%$ for $9,89 \%$ for 15; (c) 5-methy-3-isoxazolol, $\mathrm{PPh}_{3}$, DIAD, THF, $24 \mathrm{~h}$, $52 \%$; (d) TBAF, THF, $0^{\circ} \mathrm{C}, 1 \mathrm{~h}, 80 \%$ for $\mathbf{1}, 80 \%$ for $3,60 \%$ for 4 . (e) $p$-TsCl, pyr, $\mathrm{CH}_{2} \mathrm{Cl}_{2}, 24 \mathrm{~h}$, $\left(40^{\circ} \mathrm{C}\right) 88 \%$ for $11,\left(90^{\circ} \mathrm{C}\right) 90 \%$ for $16(\mathrm{f}) \mathrm{NaN}_{3}, \mathrm{DMF}, 100{ }^{\circ} \mathrm{C}, 48 \mathrm{~h}, 96 \%$ for $12,72 \%$ for $17 ;(\mathrm{g})$ 4-ethynyltoluene, sodiumascorbate $1 \mathrm{M}, \mathrm{CuSO}_{4} \cdot 5 \mathrm{H}_{2} \mathrm{O} 0.3 \mathrm{M}, t-\mathrm{BuOH} / \mathrm{H}_{2} \mathrm{O}, 48 \mathrm{~h}, 75 \%$ for $13,77 \%$ for 18 .

Considering that deprotection conditions used for silyl ethers cleavage was, in principle, compatible with the presence of the isoxazole ring, we decided first to selectively remove the benzyl ether group, with $\mathrm{BCl}_{3}$ at low temperature, to obtain the known lactone $\mathbf{9}$, already described in our previous work, in good yield. ${ }^{27}$

The heterocyclic ring 5-methy-3-isoxazolol, a commercial product known as himexazole that is employed as a pesticide, was previously synthesized according two different methods described in the literature. ${ }^{28}$ A convergent strategy based on the Mitsunobu reaction was used to couple this heterocyclic ring to the free hydroxyl group of lactone $\mathbf{9}$, using DIAD and $\mathrm{PPh}_{3}$, to produce compound $\mathbf{1 0}$ in moderate yield (52\%). Selective desilylation of the tertbutyldiphenylsilyl ether (TBDPS) group under standard conditions (TBAF) was carried out in excellent yield, obtaining the first heterocyclic-containing DAG-lactone 1 (Scheme1).

In the last decade the use of triazoles in medicinal chemistry has received marked attention, leading to the development of regioselective methodologies based on Huisgen 1,3-dipolar cycloaddition. We envisioned the synthesis of triazole analogues in the archetypical "click" reaction: the Huisgen $[3+2]$ cycloaddition between alkynes and azides catalyzed by copper (I) salts $(\mathrm{Cu}-\mathrm{AAC})$, that conduce to the regioselective formation of 1,4 -regioisomer. ${ }^{29}$ With that idea in mind, the hydroxyl group in compound 9 was transformed to the corresponding tosylate, with tosyl chloride in pyridine, which in turn was treated with sodium azide in DMFat elevated temperature yielding azide $\mathbf{1 2}$ in $85 \%$ yield, for both steps. Preparation of triazole $\mathbf{1 3}$ was carried out using the click reaction as a key step, between azide12 and a commercial alkyne, 4-ethynyl 
toluene, in the presence of $\mathrm{CuSO}_{4}$ and sodium ascorbate, a well-known catalytic system. ${ }^{30,31}$ The reaction proceeded regioselectively at room temperature to give $\mathbf{1 3}$, as the 1,4-regioisomer exclusively, in $75 \%$ yield, although a long reaction time (48 hours) was required to achieve full conversion (Scheme1). Deprotection of the TBDPS group was accomplished under standard conditions (TBAF) to obtain triazole 3 in $80 \%$ yields.

The introduction of variations in the patterns of the substituents attached to the $s n-1$ and $s n-2$ positions on the DAG-lactone has resulted, over the years, in the development of very powerful agonists in the low $\mathrm{nM}$ range. One of the most potent analogues prepared to date, obtained by Márquez's group, was the DAG-lactone AJH-836. Encouraged by this, we decided to synthesize heterocyclic DAG-lactones maintaining the same alkyl substituent present in $\mathbf{A J H - 8 3 6}$ at the $s n$ 2 position. In this sense, aldehyde 5-methyl-3-(2-methylpropyl)-hexan-1-one was prepared according to published methods ${ }^{13,18}$ and immediately employed in an aldol condensation with lactone 7 , followed by olefination through the alkylation-elimination sequence already mentioned yielding $69 \%$ of the mixture of $E / Z$ isomers (Scheme 1). Separation of $E / Z$ geometric isomers was achieved at this stage by column chromatography. The vinyl proton corresponding to the $E$-isomer (14) appears in its 'H NMR spectrum, as a characteristic multiplet that is further downfield compared to that of the corresponding $Z$-isomer. Following the same synthetic sequence described for the preparation of triazole $\mathbf{3}$, we obtained DAG-lactone 4 with similar yields for almost every step, except for TBDPS remotion with TBAF that rendering lower yield.

Attempts to obtain the branched isoxazole 2, starting with compound $\mathbf{1 5}$ and following the strategy based on Mitsunobu coupling employed to synthesize DAG-lactone1, were unsuccessful. Consequently, we decided to change the starting material and prepared the known 
lactone $19{ }^{32}$ protected with benzyl and $p$-methoxyphenyl (PMP) groups. The $s n-2$ alkyl

substituent was introduced through condensation with the branched aldehyde mentioned before ${ }^{33}$ and, after elimination of the $p$-methoxyphenyl (PMP) protecting group, Mitsunobu coupling with isoxazolol was performed to yield compound $\mathbf{2 3}$ in $37 \%$ yield. Finally, deprotection of the benzyl group with $\mathrm{BCl}_{3}$ afforded DAG-lactone 2 in good yield (Scheme 2).

Scheme 2: Different strategies to the synthesis of isoxazole 2

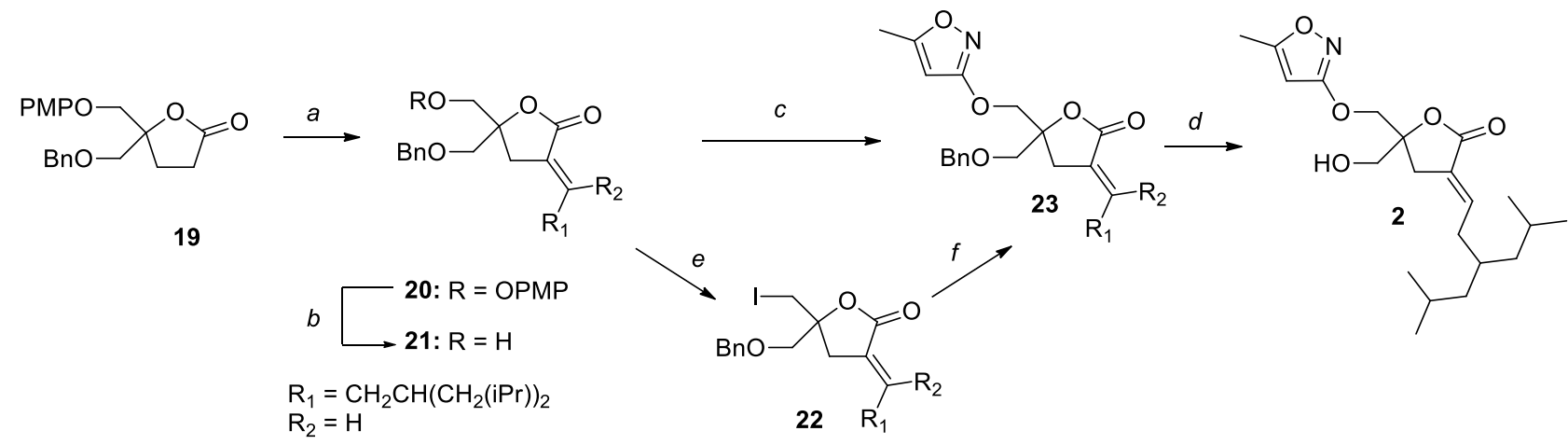

Reagents and conditions:(a) 1. 3-isobutyl-5-methylhexanal, LiHMDS, THF, - $78{ }^{\circ} \mathrm{C}, 2-4$ h; 2.(i) $\mathrm{CH}_{3} \mathrm{SO}_{2} \mathrm{Cl}, \mathrm{Et}_{3} \mathrm{~N}, 0{ }^{\circ} \mathrm{C}, 5 \mathrm{~h}$; (ii) DBU, $\mathrm{CH}_{2} \mathrm{Cl}_{2}$, room temp, $24 \mathrm{~h}, 35 \%$ for 20 (69\% for $\mathrm{E} / \mathrm{Z}$ mixture); (b) $\mathrm{CAN}, \mathrm{H}_{2} \mathrm{O} / \mathrm{CH}_{3} \mathrm{CN}, 75 \%$; (c) 5-methy-3-isoxazolol, $\mathrm{PPh}_{3}$, DIAD, THF, 24 h, 37\% ; (d) $\mathrm{BCl}_{3}$, $\mathrm{CH}_{2} \mathrm{Cl}_{2},-78{ }^{\circ} \mathrm{C}, 0.5 \mathrm{~h}, 67 \%$; (e) $\mathrm{I}_{2}, \mathrm{PPh}_{3}$, imidazole, toluene, $90{ }^{\circ} \mathrm{C}, 1 \mathrm{~h}, 89 \%$; (f) $\mathrm{K}_{2} \mathrm{CO}_{3}, \mathrm{DMF}$, sealed tube, $140{ }^{\circ} \mathrm{C}, 4 \mathrm{~h}, 62 \%$.

In view of the low yields obtained, it was decided to test an alternative synthetic route. The conversion of hydroxyl group in compound $\mathbf{2 1}$ to an iodide group was carried out with iodine in the presence of $\mathrm{PPh}_{3}$ and imidazole, in excellent yield. ${ }^{34}$ To favor the substitution reaction, compound 22 was treated with isoxazolol and a base $\left(\mathrm{K}_{2} \mathrm{CO}_{3}\right)$ at elevated temperature, in a sealed tube, obtaining the same intermediate $\mathbf{2 3}$ in higher yield (55\% in two steps) than the Mitsunobu $\operatorname{approach}^{35}$

Both synthetic strategies used in the preparation of isoxazole derivatives could, in principle, be applied in obtaining tetrazole analogues. We decided to prepare derivatives from 5-phenyl-1H- 
tetrazole, a commercially available compound that is easily prepared according literature procedures by a cycloaddition reaction between benzonitrile and sodium azide catalyzed by copper. ${ }^{36}$ Considering that the Mitsunobu route was straightforward, we tried the coupling between tetrazole 28 and the known lactone $25^{37}$ (Scheme 3). Unfortunately, the reaction did not proceed well, and a complex inseparable mixture was obtained in a very low total yield of $17 \%$. Hence, the alternative strategy based on the nucleophilic substitution of a good leaving group, such as iodine, by the phenyltetrazole anion generated in situ in the presence of base, was attempted. Indeed, compound $\mathbf{2 7}$ was obtained in $70 \%$ yield from $\mathbf{2 5}$ (two steps). Based on twodimensional NMR experiments, it was concluded that the 2,5-disubstituted regioisomer was obtained as the only product. Finally, benzyl deprotection led to derivative $\mathbf{5}$. In this case, when we tested the Mitsunobu reaction, employing branched lactone 21 and compound 28, we succeeded in introducing tetrazole ring into compound $\mathbf{2 9}$ in moderate yield. Benzyl deprotection under standard conditions gave the tetrazolic DAG-lactone 6(Scheme 3).

Scheme 3: Synthesis of tetrazole analoguesDAG-lactone 5 and DAG-lactone 6

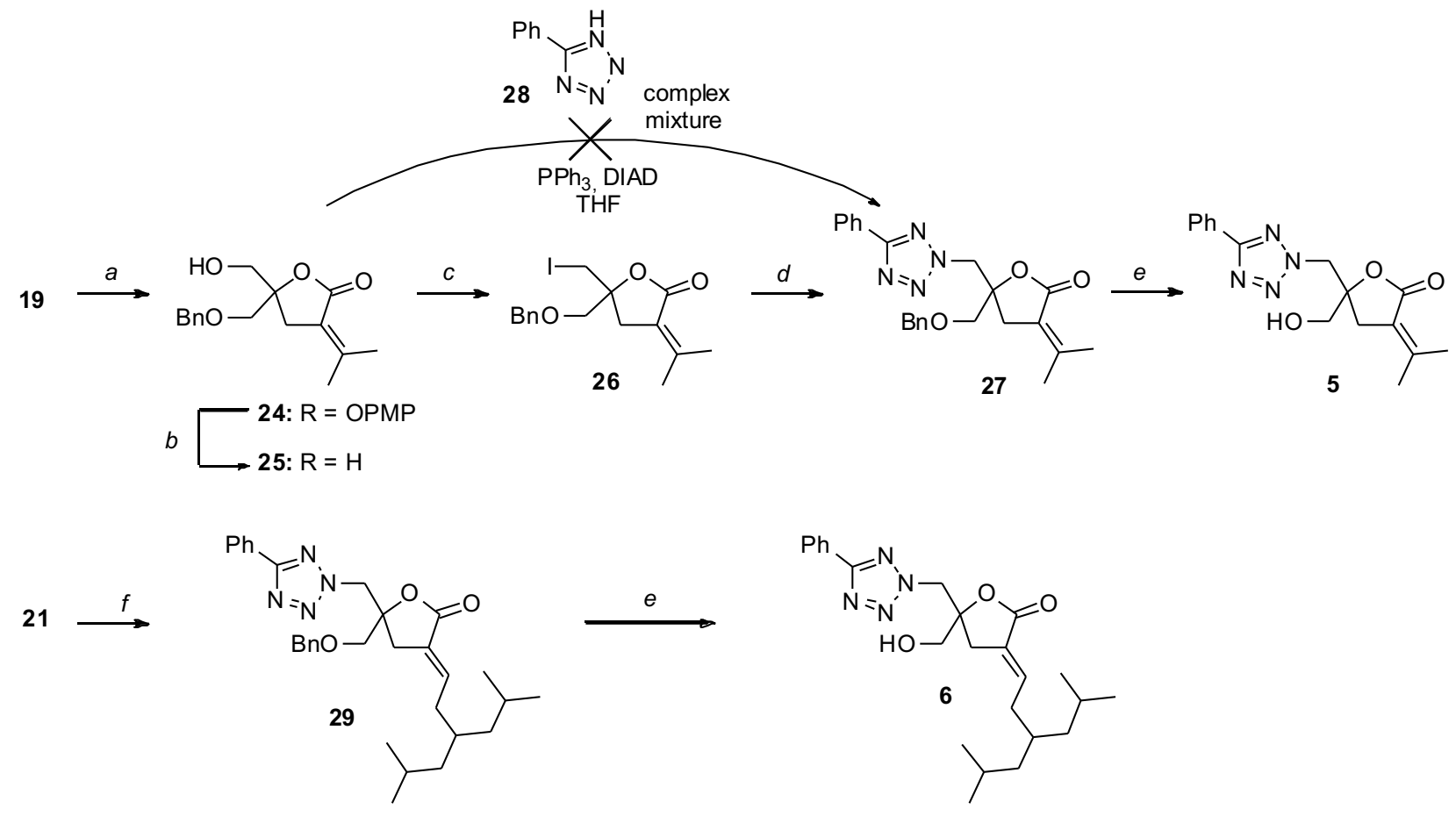


Reagents and conditions: (a) 1. acetone, LiHMDS, THF, $-78{ }^{\circ} \mathrm{C}, 2-4 \mathrm{~h}$; 2.(i) $\mathrm{CH}_{3} \mathrm{SO}_{2} \mathrm{Cl}, \mathrm{Et}_{3} \mathrm{~N}, 0$ ${ }^{\circ} \mathrm{C}, 5 \mathrm{~h}$; (ii) DBU, $\mathrm{CH}_{2} \mathrm{Cl}_{2}$, room temp, $24 \mathrm{~h}, 90 \%$ for 24 ; (b) $\mathrm{CAN}, \mathrm{H}_{2} \mathrm{O} / \mathrm{CH}_{3} \mathrm{CN}, 92 \%$; (c) $\mathrm{I}_{2}, \mathrm{PPh}_{3}$, imidazole, toluene, $90{ }^{\circ} \mathrm{C}, 1 \mathrm{~h}, 95 \%$; (d) 5-phenyl- $1 \mathrm{H}$-tetrazole, $\mathrm{K}_{2} \mathrm{CO}_{3}$, DMF, sealed tube, $120^{\circ} \mathrm{C}$, 20 h, 74\%; (e) $\mathrm{BCl}_{3}, \mathrm{CH}_{2} \mathrm{Cl}_{2},-78{ }^{\circ} \mathrm{C}, 0.5 \mathrm{~h}, 90 \%$ for 5, 78\% for 6; (f) 5-phenyl-1H-tetrazole, $\mathrm{PPh}_{3}$, DIAD, THF, $24 \mathrm{~h}, 53 \%$.

\section{Biological Results}

\subsection{In vitro binding of novel heterocyclic DAG-lactones to PKC isozymes}

In order to determine the affinity of the newly synthesized DAG-lactones, we used an established in vitro competition binding assay, with $\left[{ }^{3} \mathrm{H}\right]$ phorbol 12,13 -dibutyrate $\left(\left[{ }^{3} \mathrm{H}\right] \mathrm{PDBu}\right)$ as a radioligand. The assay was carried out in the presence of $100 \mu \mathrm{g} / \mathrm{ml}$ phosphatidylserine, as previously described (for more details see General Procedure section). ${ }^{38} \mathrm{We}$ first examined the affinity of the compounds for PKCa. Results revealed that DAG-lactone 2, from now on 10B12, could compete $\left[{ }^{3} \mathrm{H}\right] \mathrm{PDBu}$ with a $\mathrm{Ki}=79.3 \mathrm{nM}$. The other DAG-lactones only marginally displaced the radioligand at a concentration of $30 \mu \mathrm{M}$. For comparison, the DAG-lactone AJH836 bound to $\mathrm{PKC} \alpha$, with a $\mathrm{Ki}=23.6 \mathrm{nM} .{ }^{16}$ We next determined the ability of $\mathbf{1 0 B 1 2}$ to bind to $\mathrm{PKC} \varepsilon$. Competition assays revealed that the Ki for PKC $\varepsilon$ was 2.4-fold lower than that for PKC $\alpha$ (33.6 nM), suggesting a marginal, yet significant preference for the $\mathrm{nPKC}$, at least in vitro. For comparison, AJH-836 displayed a $\mathrm{Ki}=1.89 \mathrm{nM}$ for $\mathrm{PKC} \varepsilon$, therefore showing 12.4-fold lower $\mathrm{Ki}$ than that for PKC $\alpha .{ }^{16}$ Two of the DAG-lactones with limited binding for PKC $\alpha$ (4 and $\mathbf{6}$ ) were also examined for their ability to bind $\mathrm{PKC} \varepsilon$, and they were found to display limited binding for this $\mathrm{nPKC}$ using a fixed concentration of $30 \mu \mathrm{M}$ (Table 1). 
Table 1. DAG-lactones binding affinities for $\mathrm{PKC} \alpha$, and $\mathrm{PKC} \varepsilon$ in vitro

\begin{tabular}{|c|c|c|c|}
\hline \multirow{2}{*}{ Compound } & \multirow{2}{*}{$\mathrm{Clog} \mathrm{P}$} & \multicolumn{2}{|c|}{$\begin{array}{c}\mathbf{K i}(\mathbf{n M}) \\
\text { (or \% inhibition, if partial) }\end{array}$} \\
\hline & & PKC $\alpha$ & PKCE \\
\hline АJH-836 & 5.52 & $23.6 \pm 2.0^{16}$ & $1.89 \pm 0.20^{16}$ \\
\hline 1 & 0.78 & $31.3 \%$ at $30 \mu \mathrm{M}$ & N.D. \\
\hline $\begin{array}{c}2 \\
(10 B 12) \\
\end{array}$ & 4.75 & $79.3 \pm 20.7$ & $33.6 \pm 6.8$ \\
\hline 3 & 2.61 & $11.7 \%$ at $30 \mu \mathrm{M}$ & N.D. \\
\hline 4 & 6.58 & $21.3 \%$ at $30 \mu \mathrm{M}$ & $17 \%$ at $10 \mu \mathrm{M}$ \\
\hline 5 & 2.08 & $23.5 \%$ at $30 \mu \mathrm{M}$ & N.D. \\
\hline 6 & 6.05 & $37.5 \%$ at $30 \mu \mathrm{M}$ & $69.2 \%$ at $30 \mu \mathrm{M}$ \\
\hline
\end{tabular}

Values represent the mean \pm S.E.M of three independent experiments and were calculated from the $\mathrm{ID}_{50}$ values determined from the competition curves. N.D.: non-determined. ClogP calculated in ChemDraw.

Previous studies with chemical series of DAG-lactones have shown that there is a parabolic relationship betweenC1 domain binding affinity and $\log \mathrm{P}$, with a peak at a $\log \mathrm{P}$ of approximately 5. A $\log \mathrm{P}$ close to this value gives compounds adequate lipophilicity required for partitioning into membranes with the lowest possible amount of non-specific membrane affinity. ${ }^{10}$ Of the heterocyclic DAG-lactones, compounds $\mathbf{1 0 B 1 2}$ and 6 are closest in $\log \mathrm{P}$ value to the model compound AJH-836 and closest to this $\log$ P "sweet spot", suggesting that these compounds have the ideal balance between membrane and $\mathrm{C} 1$ domain binding ability.

\subsection{Differential translocation of PKC $\alpha$ and PKC $\varepsilon$ by heterocyclic DAG-lactones in cells}


While binding assays using reconstituted $100 \%$ phosphatidylserine vesicles is a well-accepted approach to determine the in vitro binding affinities of $\mathrm{C} 1$ domain ligands to $\mathrm{PKC}$ isozymes, assessing their effects in cellular models provides more reliable information about their ability activating these kinases in their physiological environment. Indeed, small differences in Ki's of for individual PKCs, as determined in vitro, may translate into significant differences in isozyme specificity in cellular-based assays. We therefore examined the ability of heterocyclic DAG lactones to translocate PKC isozymes to membranes, a well-established hallmark of enzyme activation in cells. As an experimental strategy, we expressed Green Fluorescence Protein (GFP)-fused PKC $\alpha$ or PKC $\varepsilon$ in HeLa cervical adenocarcinoma cells and examined the ability of DAG lactones to induce kinase relocalization to the plasma membrane using fluorescence microscopy. Coupling this imaging analysis to the determination of membrane to cytosol fluorescent ratio allows an accurate quantification of enzyme translocation and the precise determination of potencies in cellular models. Using this approach, we determined that AJH-836 displays 43-foldhigher potency for translocation of PKCE relative to PKC $\alpha .{ }^{16}$ As shown in the images from Fig. 4A and subsequent quantification of the membrane/cytosol fluorescence ratio in Fig. 4B, 10B12 (2) and $6(1 \mu \mathrm{M})$ induced an evident redistribution of fluorescence in GFPPKC $\varepsilon$ expressing HeLa cells. On the other hand, compounds 1, 3, 4 and 5 had essentially no effect on GFP-PKC $\varepsilon$ redistribution, and fluorescence remained cytoplasmic after treatment. As controls, we found that the phorbol ester PMA (100 nM), which displays similar activity on cPKCs and nPKCs, fully translocated GFP-PKC $\alpha$ and GFP-PKC $\varepsilon$ to the plasma membrane, whereas the PKC $\varepsilon$-selective DAG lactone AJH-836 $(1 \mu \mathrm{M})$ only translocated GFP-PKC $\varepsilon$, as we established in a previous study. ${ }^{16}$ 


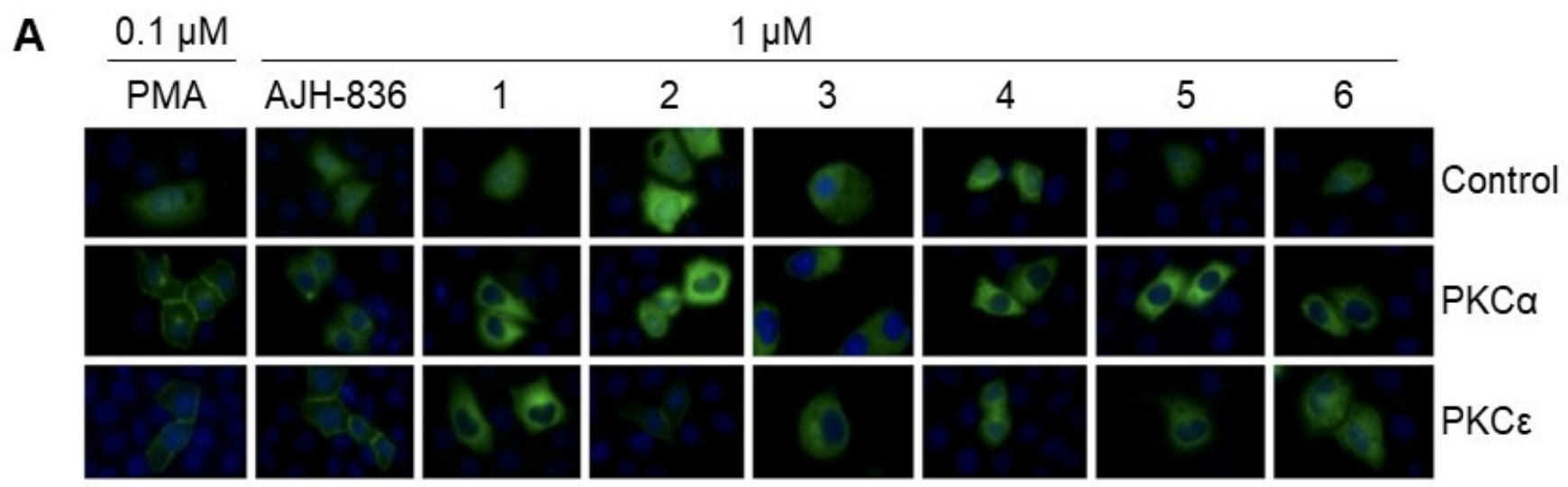

B

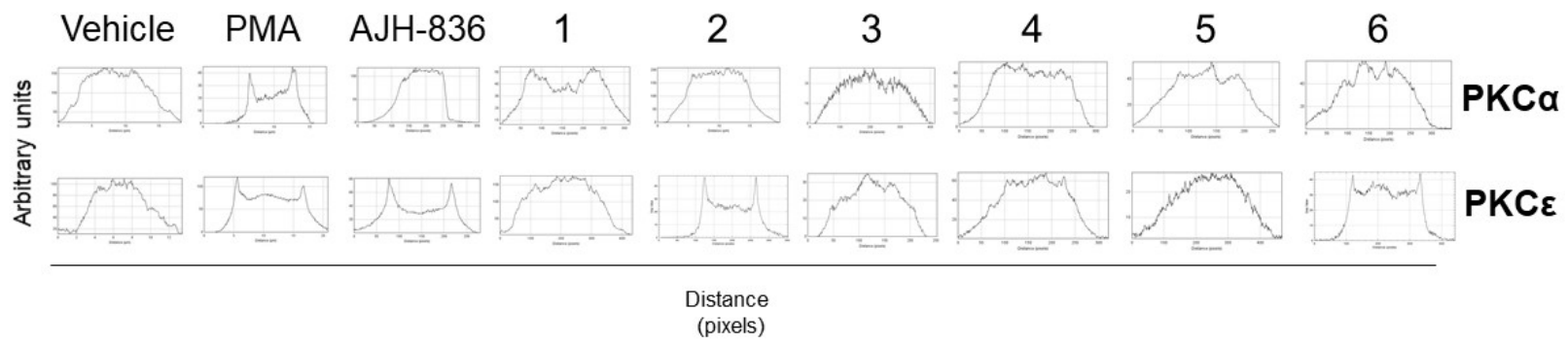

C

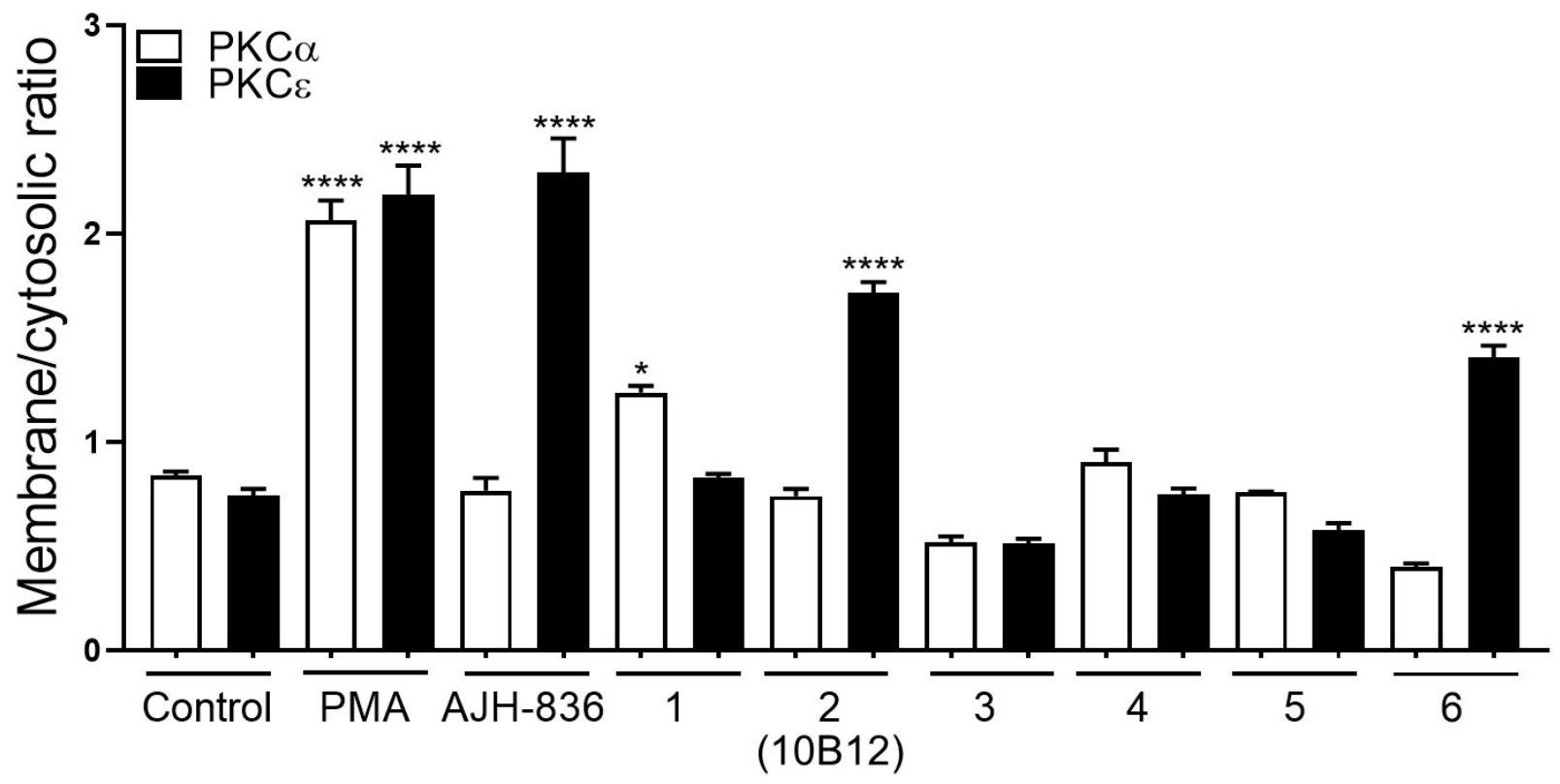

Figure 4. Translocation of PKC isozymes by DAG-lactones. HeLa cells expressing GFP (control), GFP-PKC $\alpha$ or GFP-PKC $\varepsilon$ were stimulated for $30 \mathrm{~min}$ with the indicated compounds, fixed, and visualized by fluorescent microscopy. Panel $A$. Representative micrographs are shown. Panel B. Representative graphs obtained using Image $\mathrm{G}$ that depict the quantification of membrane/cytosol ratio. Panel C. Membrane/cytosol ratio (n=5-10 cells/group). Results are expressed as mean \pm S.E.M. *, p $<0.05$. ****, $\mathrm{p}<0.001 v$ s. control. 


\subsubsection{B12 induces major changes in cytoskeletal morphology}

In order to pursue a deeper biological characterization of the heterocyclic DAG-lactones, we next examine a cellular function known to be specifically mediated by PKCE. Specifically, $\mathrm{PKC} \varepsilon$, but not $\mathrm{PKC} \alpha$, is the $\mathrm{PKC}$ implicated in the formation of membrane ruffles, actin-rich protrusions involved in cancer cell motility. Indeed, both PMA- and AJH-836-induced ruffle formation in A549 lung cancer cells was severely affected upon silencing PKC $\varepsilon$ by means of RNA interference (RNAi) or pre-treatment with a selective PKC $\varepsilon$ pharmacological inhibitor. ${ }^{16}$ To address the effect of the newly synthesized DAG-lactones on ruffle formation, we treated A549 cells with the different compounds ( $1 \mu \mathrm{M}, 30 \mathrm{~min})$, and then subjected cells to polymerized actin staining using phalloidin. Upon microscopy examination, we observed a prominent stimulation of ruffle formation upon treatment with 10B12. No effects were observed for the other synthesized DAG-lactones, other than a small response by DAG-lactone 6 (Fig. $5 A)$. Quantification of ruffle formation using a densitometric approach ${ }^{16}$ revealed that the effect of $10 \mathrm{~B} 12$ was near the maximum response caused by $1 \mu \mathrm{M}$ AJH-836 and $100 \mathrm{nM}$ PMA (Fig. $5 \mathrm{~B})$. We also tested a higher dose of the DAG lactones $(10 \mu \mathrm{M})$, but at this concentration those compounds that induce ruffles at $1 \mu \mathrm{M}$ showed significant toxicity, as evidenced by cell detachment and death (data not shown). The rank in potency observed in these experiments essentially matched that observed for GFP-PKC $\varepsilon$ peripheral translocation. 
A

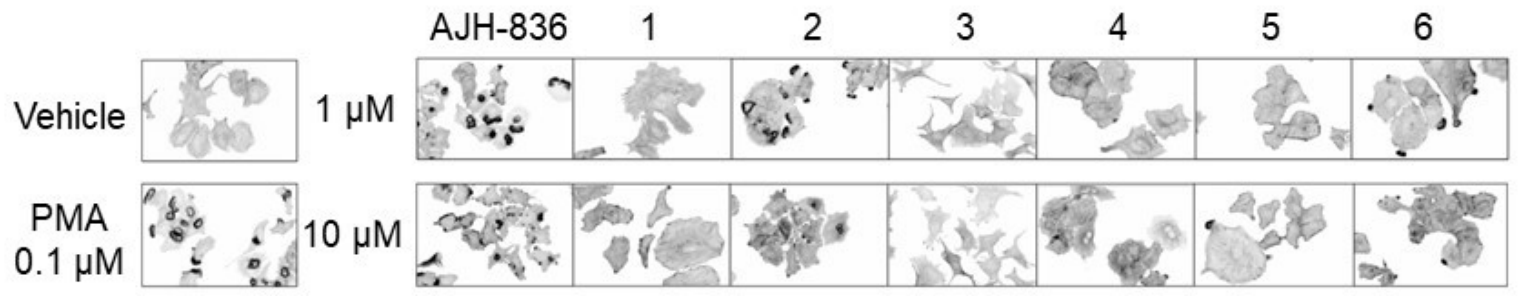

B

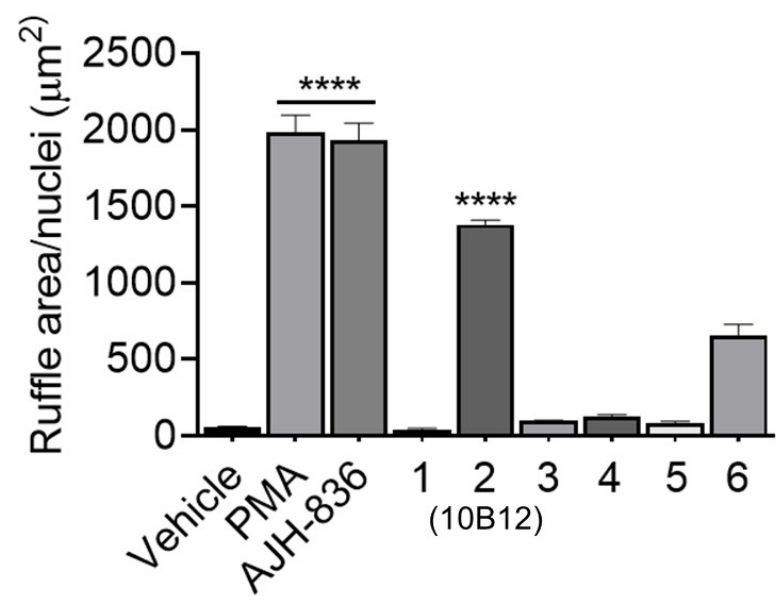

Figure 5. Stimulation of ruffle formation by DAG-lactones. A549 cells were stimulated for 30 min with DAG-lactones $(1 \mu \mathrm{M})$ or PMA $(0.1 \mu \mathrm{M})$. Cells were fixed and stained with phalloidinrhodamine. Panel A. Representative micrographs. Panel B. Quantification of ruffle area/cell using Image J. ${ }^{* * * *}, \mathrm{p}<0.001 v s$. vehicle.

Finally, in order to confirm the involvement of PKC $\varepsilon$ in the formation of ruffles induced by 10B12, we used PKC $\varepsilon$ RNAi to silence the expression of this kinase in A549 cells. In order to minimize misinterpretations due to "off-target" effects of RNAi duplexes, we used two different RNAi duplexes ( $\varepsilon 1$ and $\varepsilon 2$ ). We observed $80-90 \%$ reduction in PKC $\varepsilon$ mRNA levels (as determined by Q-PCR) (Fig. 6A) and $\sim 70 \%$ reduction in PKC $\varepsilon$ protein expression (as determined by Western blot) $48 \mathrm{~h}$ after transfection of either RNAi duplex (Fig. 6B). Notably, the formation of ruffles by $10 \mathrm{~B} 12$ was markedly impaired in $\mathrm{PKC} \varepsilon$-depleted cells in a magnitude 
that was consistent with its depletion (Fig. 6C), as was previously observed with AJH-836 using a similar approach..$^{16}$ Together with the membrane translocation studies, these actin reorganization experiments establish $\mathbf{1 0 B 1 2}$ as a bona-fide $\mathrm{PKC} \varepsilon$ activating DAG-lactone.

A

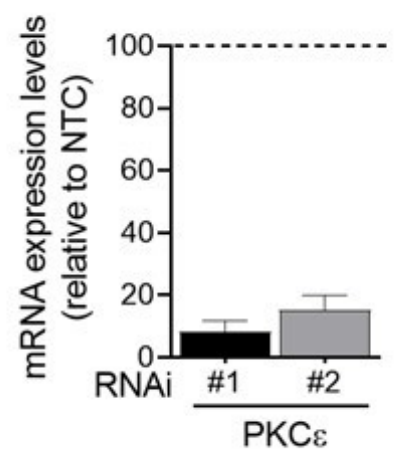

B
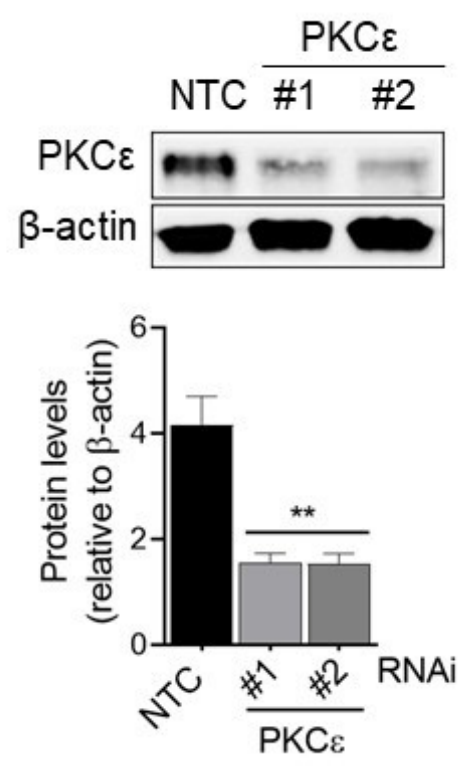

C

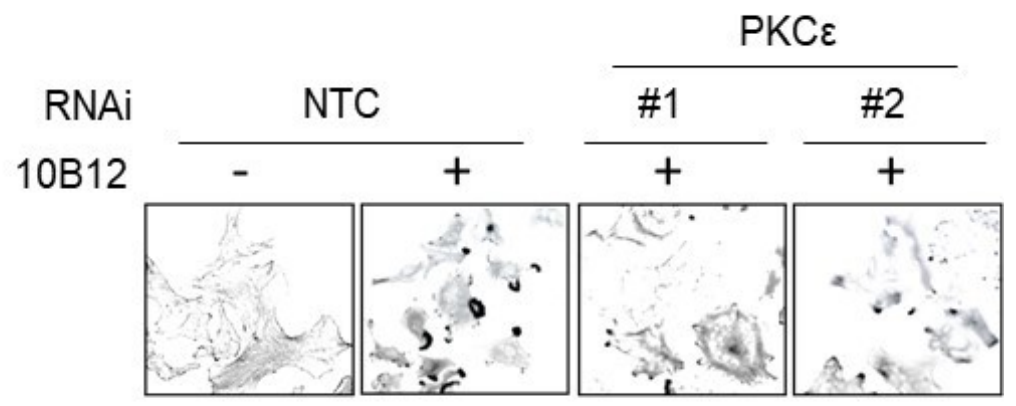

D

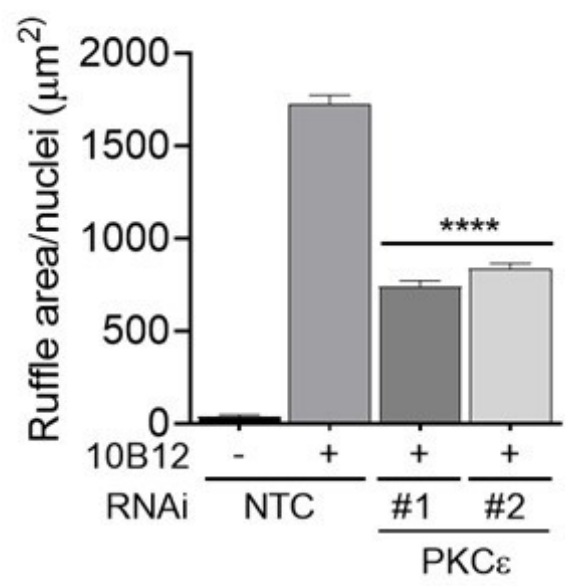

Figure 6. PKC $\varepsilon$ mediates the ruffle formation response of compound 10B12. A549 cells were subjected to PKC $\varepsilon$ RNAi by delivery of specific siRNA duplexes (PKC\&\#l and PKCE\#2). As a control, cells were transfected with a non-target control (NTC) siRNA duplex. Experiments were carried out $48 \mathrm{~h}$ later. Panel A. PKC $\varepsilon$ mRNA levels relative to NTC (dotted line). Panel $B$. $\mathrm{PKC} \varepsilon$ protein levels. Upper panel, representative Western blot. Lower panel, densitometric analysis of $\mathrm{PKC} \varepsilon$ protein levels, expressed as arbitrary units relative to $\beta$-actin. Panel C. A549 cells were stimulated for $30 \mathrm{~min}$ with 10B12 $(1 \mu \mathrm{M})$, fixed and stained with phalloidinrhodamine. Upper panel. Representative micrographs. Lower panel. Quantification of ruffle area/cell using Image J. ****, $\mathrm{p}<0.001$ vs.10B12-treated cells, NTC. 


\section{CONCLUSION}

Along the past decades, a large number of DAG-lactones analogues with broad structural variation have been designed and synthesized, generating diversity at the $s n-1$ and $s n-2$ positions and covering an extensive chemical space. Most of these compounds have an ester moiety at the $s n-1$ position that is important for receptor interaction, and only a few attempts have been done to replace it. In this study, different types of heterocyclic groups were introduced as substituents for the DAG-lactone structure at $s n-1$ position. Synthetic strategies were developed for the introduction of isoxazolol, triazole and tetrazole rings as ester moiety replacements. The isoxazolol ring was introduced in DAG-lactone $\mathbf{1}$ by a Mitsunobu approach starting from lactone 7. A change in the protective groups of the starting material, following the Mitsunobu route, led the analogues with a saturated-branched alkyl chain at $s n-2$ position (DAG-lactone $2,10 B 12)$ in low yields. An improvement in the $\mathbf{2}$ yield was achieved by employing a synthetic alternative based in a substitution reaction. Triazole analogues $\mathbf{3}$ and $\mathbf{4}$ were obtained in good yields by methodologies based on the copper (I) catalyzed variant of the Huisgen 1,3-dipolar cycloaddition between alkynes and azides catalyzed. The first attempts to introduce tetrazole ring in DAGlactones 5 and $\mathbf{6}$ were carried out in Mitsunobu conditions. Compound $\mathbf{6}$ was straightforwardly obtained by this route, but the strategy did not proceed well for compound $\mathbf{5}$, which was obtained using the alternative based on the nucleophilic substitution of a good leaving group by the phenyltetrazole anion.

Modeling predicted that compound 10B12, with its higher $\log \mathrm{P}$ and its ability to adopt the favored sn-2 binding mode for DAG-lactones, would have a stronger C1 domain binding ability. 
The present results highlight the feasibility for generating $\mathrm{C} 1$ domain ligands with preferential selectivity towards specific members of the PKC family, a highly complex task due to the remarkable similarity among $\mathrm{C} 1$ domains. Agents that belong to the different families of DAG ligands, such as phorbol esters, deoxyphorbol esters and bryostatins, display similar affinities in vitro for individual PKC isoforms. However, as reported in early studies, the ability of $\mathrm{C} 1$ domain ligands in in vitro binding assays does not necessarily reflects their ability to promote their association with membranes, ${ }^{39,40}$ ultimately resulting in diverse biological functions. This is epitomized by bryostatins and deoxyphorbol esters, compounds that display anti-tumor promoting activities in mouse models rather than the typical tumor promoting effects caused by phorbol esters. Although not fully understood, it may be possible that additional mechanisms, namely the interactions of ligands with lipid microdomains and/or the formation of specific ligand-protein-membrane ternary complexes may greatly influence biological responses of $\mathrm{C} 1$ domain-binding compounds. While these mechanisms still remain subjected to experimental examination, it is clear that such rich diversity in the effects of $\mathrm{C} 1$ domain ligands underscore opportunities for the generation of PKC isozyme-specific ligands. In this regard, our data is in line with previous studies demonstrating that it is possible to achieve remarkable selectivity upon introduction of side chains incyclicized DAG structures, as has been previously demonstrated by means of combinatorial libraries for DAG-lactones with different alkyl-chain and acyl-chain substitutions.

In previous studies, we demonstrated remarkable selectivity towards PKC $\varepsilon$ for the DAGlactone AJH-836. This derivative represents to-date the best characterized example for a cyclized DAG with preferential selectivity for an $\mathrm{nPKC}$ relative to cPKCs. ${ }^{16,17,41}$ Similar to AJH836, the DAG-lactone 10B12 synthesized in the present study, in which the ester moiety at the 
$s n-1$ position has been replaced by an isoxazole ring, displays a significant degree of specificity for $\mathrm{PKC} \varepsilon$ relative to $\mathrm{PKC} \alpha$, particularly in a cellular context. Indeed, although the $\left[{ }^{3} \mathrm{H}\right] \mathrm{PDBu}$ competition binding assays revealed lower $\mathrm{PKC} / \mathrm{PKC} \alpha$ selectivity index for $10 \mathrm{~B} 12$ compared to AJH-836, it shows a preferred ability to translocate $\mathrm{PKC} \varepsilon$ relative to $\mathrm{PKC} \alpha$. This selectivity is reflected in its ability to induce the reorganization of the cellular actin cytoskeleton into peripheral ruffles, a well described PKC $\varepsilon$-mediated effect. We carefully validated this conclusion by means of PKC $\varepsilon$ RNAi silencing, which was able to abrogate the activity of the new $s n-1$ derivative to form ruffles in lung cancer cells. Thus, a stable isoxazole ring can function as an ester surrogate to allow binding to $\mathrm{C} 1$ domain and dictate specificity towards $\mathrm{PKC} \varepsilon$ as a receptor in a cellular environment. Since $\mathrm{PKC} \varepsilon$ is very important for tumor growth and metastasis and has been implicated in cancer cell motility and invasiveness, ${ }^{42,43}$ novel $s n-1$ derivative may have significant utility for the study of this kinase in cancer progression. Considering the limited availability of isozyme-specific PKC activators, this class of $\mathrm{C} 1$ domain ligands may represent a novel tool that promotes PKC isozyme biological response patterns.

In summary, our study provides proof-of-principle for the generation of DAG-lactones with replacements in the labile ester group at the $s n-1$ position having significant potency for PKC activation. DAG-lactones with a stable isoxazole ring that can function as an ester surrogate represent a novel class of PKC activators, thus expanding the diversity of $\mathrm{C} 1$ domain ligands with PKC isozyme selectivity. Given the simplicity of the DAG-lactone structure for chemical modifications, the search for additional substitutions could help in the design of additional potent nPKC selective agents for experimentally assessing the functional involvement of these kinases in human disease. 


\section{EXPERIMENTAL SECTION}

General Procedures. All chemical compounds were purchased from commercial sources or synthesized. All final products were at least $95 \%$ pure, as determined by ${ }^{\prime} \mathrm{H}$ NMR. Reaction monitoring was performed on Merck silica gel 254F TLC plates. Column chromatography was performed on a Teledyne Isco CombiFlash $\mathrm{Rf}+$ instrument under gradient elution conditions with RediSep disposable flash columns. All melting points were determined on an Electrothermal IA9000 series digital melting point apparatus and are uncorrected. ${ }^{1} \mathrm{H}$ NMR and ${ }^{13} \mathrm{C}$ NMR spectra were carried out on Bruker Fourier 300, $300 \mathrm{MHz}$ or Bruker Avance DPX 400, $400 \mathrm{MHz}$ spectrometer using $\mathrm{CDCl}_{3}, \mathrm{MeOD}$ or DMSO- $d_{6}$ as the solvent and TMS as internal standard. HRMS was performed at CIBION (Bioanalytical Mass Spectrometry Group). High resolution positive ion electrospray ionization MS was conducted on a Xevo G2S Q-TOF spectrometer (Waters Corporation, Manchester, UK) operated at both positive and negative modes. Data processing was carried out using MassLynx v4.1 software (Waters Corp.). Data was corrected during acquisition using a reference compound (LockSpray). All title compounds were examined for PAINS and passed. ${ }^{44}$

Docking Studies. Compounds were docked into the crystal structure of the C1B domain of PKC $\delta^{14}$ using the program GOLD, version 5.2.2..$^{45,46}$ We used standard default genetic algorithm (GA) settings, with the binding site defined by atoms within a $10.0 \AA$ radius of the $\mathrm{N} \varepsilon$ atom of residue Q257. The scoring function was GoldScore, and we added a template similarity constraint to the hydrogen bond acceptor atoms in bound phorbol-13-O-acetate from the crystal structure. Twenty GA runs were performed for each compound. After docking, the docked poses were refined with 500 steps of conjugate gradient energy minimization using the Embrace facility in MacroModel. ${ }^{47}$ 
The ligand and residues 240-242, 250-253, and 257 in the $\mathrm{C} 1$ domain were free to move, residues 237-239, 243, and 254-256 were restrained with a force constant of $100 \mathrm{~kJ} / \mathrm{mol} \cdot \AA 2$, and all other protein residues were fixed in place.

\section{Chemistry}

\section{General Procedure A. Aldol condensation followed by olefination.}

\section{Standard Alkylation Procedure}

A solution of lactone 7 or 19 (1 equiv) in THF $(5 \mathrm{~mL} / \mathrm{mmol})$ at $-78{ }^{\circ} \mathrm{C}$ was treated dropwise with LiHMDS (1.5-2.0 equiv, $1 \mathrm{M}$ in THF). After the mixture was stirred at $-78^{\circ} \mathrm{C}$ for $1 \mathrm{~h}$, a solution of $\mathrm{R}_{2} \mathrm{CHO}$ (1.5 equiv) or acetone ( 5 equiv) in THF ( $1 \mathrm{~mL} / \mathrm{mmol}$ ) was added and the stirring continued for $2-3 \mathrm{~h}$ at $-78^{\circ} \mathrm{C}$. The reaction was quenched by slow addition of a saturated aqueous solution of $\mathrm{NH}_{4} \mathrm{Cl}$ and allowed to warm to room temperature. The layers were separated, and the aqueous layer was extracted with $\mathrm{Et}_{2} \mathrm{O}(3 \times)$. The combined organic phases were washed with $\mathrm{H}_{2} \mathrm{O}(1 \times)$ and brine $(1 \times)$, dried over $\mathrm{MgSO}_{4}$, and concentrated in vacuo. Purification by silica gel flash column chromatography (gradient 0-20\% EtOAc/hexanes) gave a mixture of alcohols diastereomers, which were used directly in the next step.

\section{Standard Mesylation-Olefination Procedure}

A solution of the alkylation product in dichloromethane $(10 \mathrm{~mL} / \mathrm{mmol})$ at $0{ }^{\circ} \mathrm{C}$ was treated with methanesulfonyl chloride ( 2 eq) and triethylamine (4 eq) and then stirred at room temperature for 2-5 h. DBU (3-5 equiv) was added at $0{ }^{\circ} \mathrm{C}$, and the resulting solution was stirred overnight at 
ambient temperature. The reaction mixture was treated with a saturated solution of $\mathrm{NH}_{4} \mathrm{Cl}(10$ $\mathrm{mL} / \mathrm{mmol})$ and extracted with $\mathrm{CH}_{2} \mathrm{Cl}_{2}(3 \times)$. The combined organics were washed with $\mathrm{H}_{2} \mathrm{O}(2 \times)$ and brine $(1 \times)$, dried $\left(\mathrm{Na}_{2} \mathrm{SO}_{4}\right)$, and concentrated in vacuo. Purification by silica gel flash column chromatography (gradient 0-20\% EtOAc/hexanes) gave 14, 20 and 24.

\section{General Procedure B. BnO Deprotection.}

A solution of 14, 22, 27 or 29 (1 equiv) in anhydrous dichloromethane $(20 \mathrm{~mL} / \mathrm{mmol})$ at $-78^{\circ} \mathrm{C}$ was treated dropwise with boron trichloride ( $1 \mathrm{M}$ in $\mathrm{CH}_{2} \mathrm{Cl}_{2}, 2$ equiv). The reaction was monitored by TLC and quenched upon completion $(0.5-1 \mathrm{~h})$ by the slow addition of $\mathrm{NaHCO}_{3}$ and the aqueous phase was extracted with dichloromethane $(2 \times 15 \mathrm{ml})$. The organic phase was dried $\left(\mathrm{Na}_{2} \mathrm{SO}_{4}\right)$ and concentrated in vacuo. Purification by silica gel flash column chromatography (gradient 0-20\% EtOAc/hexanes) gave 15, 2, 5 and 6.

\section{General Procedure C. PMP deprotection.}

Ceric ammonium nitrate ( 3 equiv) was added to a solution of $\mathbf{2 0}$ or $\mathbf{2 4}$ ( 1 equiv) in $80 \%$ $\mathrm{CH}_{3} \mathrm{CN} / \mathrm{H}_{2} \mathrm{O}(\mathrm{v} / \mathrm{v}, 10 \mathrm{~mL} / \mathrm{mmol})$ at $0{ }^{\circ} \mathrm{C}$. The reaction mixture was stirred for $15 \mathrm{~min}$. A solution of $5 \% \mathrm{Na}_{2} \mathrm{~S}_{2} \mathrm{O}_{3}$ was added at room temperature and the aqueous phase was extracted with $\mathrm{CH}_{2} \mathrm{Cl}_{2}(3 \times)$. The organic phase was dried $\left(\mathrm{Na}_{2} \mathrm{SO}_{4}\right)$ and concentrated in vacuo. Purification by silica gel flash column chromatography (gradient 0-30\% EtOAc/hexanes) gave 21 and 25.

\section{5-(((tert-butyldiphenylsilyl)oxy)methyl)-5-(((5-methylisoxazol-3-yl)oxy)methyl)-3-(propan-2-}

\section{ylidene)dihydrofuran-2(3H)-one (10)}

A solution of triphenylphosphine $(557 \mathrm{mg}, 2.0 \mathrm{mmol})$, lactone $9^{27}(638 \mathrm{mg}, 1.5 \mathrm{mmol})$ and 5methylisoxazol-3-ol ${ }^{28}(119 \mathrm{mg}, 1.2 \mathrm{mmol})$ in anhydrous tetrahydrofuran $(6 \mathrm{~mL})$ was treated with 
diisopropyl azodicarboxylate $(410 \mu \mathrm{L}, 2.0 \mathrm{mmol})$ and stirred at room temperature overnight. The reaction mixture was evaporated and the residue was purified by flash chromatography using hexane:ethyl acetate (8:2) as eluent to afford $\mathbf{1 0}$ as a white solid (314 $\mathrm{mg}, 52 \%)$; mp: 93-94 ${ }^{\circ} \mathrm{C}$. ${ }^{1} \mathrm{H}$ NMR (400 MHz, $\left.\mathrm{CDCl}_{3}\right)$ 87.67-7.65 (m, 4H), 7.42-7.40 (m, 6H), $5.62(\mathrm{~s}, 1 \mathrm{H}), 4.38-4.32(\mathrm{~m}$, 2H), $3.78(\mathrm{~s}, 2 \mathrm{H}), 2.90(\mathrm{AB} d, J=16.4 \mathrm{~Hz}, 1 \mathrm{H}), 2.78(\mathrm{AB} \mathrm{d}, J=16.4 \mathrm{~Hz}, 1 \mathrm{H}), 2.34(\mathrm{~s}, 3 \mathrm{H}), 2.28$ (s, 3H), $1.88(\mathrm{~s}, 3 \mathrm{H}), 1.05(\mathrm{~s}, 9 \mathrm{H}) .{ }^{13} \mathrm{C} \mathrm{NMR}\left(101 \mathrm{MHz}, \mathrm{CDCl}_{3}\right) \delta 171.6,170.6,169.1,150.2$, $135.6,135.6,132.7,132.5,129.9,127.8,127.8,119.5,92.9,81.2,70.5,66.0,35.3,26.6,24.5$, 19.8, 19.1, 12.9. HRMS (ESI) $m / z$ calcd. for $\mathrm{C}_{29} \mathrm{H}_{35} \mathrm{NO}_{5} \mathrm{Si}(\mathrm{M}+\mathrm{H})^{+}:$506,2363, found. 506,2364.

\section{5-(hydroxymethyl)-5-(((5-methylisoxazol-3-yl)oxy)methyl)-3-(propan-2-} ylidene)dihydrofuran-2(3H)-one (1)

To a stirred solution of 10 (160 mg, $0.32 \mathrm{mmol})$ in anhydrous THF (3 mL) tetrabutylammonium fluoride $(1.0 \mathrm{M}$ in THF, $320 \mu \mathrm{L}, 0.32 \mathrm{mmol})$ was added at $0{ }^{\circ} \mathrm{C}$. After stirring for $1 \mathrm{~h}$ the reaction was evaporated. The residue was purified by column chromatography over silica gel with hexane:ethyl acetate (6:4) as eluent to afford $\mathbf{1}(68 \mathrm{mg}, 80 \%)$ as a white solid; mp: $139-140{ }^{\circ} \mathrm{C} .{ }^{1} \mathrm{H}$ NMR $\left(400 \mathrm{MHz}, \mathrm{CDCl}_{3}\right) \delta 5.63(\mathrm{~s}, 1 \mathrm{H}), 4.33-4.27(\mathrm{AB} \mathrm{q}, J=11.1 \mathrm{~Hz}, 2 \mathrm{H})$, $3.69(\mathrm{~m}, 2 \mathrm{H}), 3.15(\mathrm{t}, J=6.6 \mathrm{~Hz}, 1 \mathrm{H}), 2.85(\mathrm{AB} \mathrm{d}, J=16.5 \mathrm{~Hz}, 1 \mathrm{H}), 2.73(\mathrm{AB} \mathrm{d}, J=16.5 \mathrm{~Hz}$, 1H), $2.30(\mathrm{~s}, 3 \mathrm{H}), 2.23(\mathrm{~s}, 3 \mathrm{H}), 1.86(\mathrm{~s}, 3 \mathrm{H}) .{ }^{13} \mathrm{C} \mathrm{NMR}\left(101 \mathrm{MHz}, \mathrm{CDCl}_{3}\right) \delta 171.8,170.9,169.1$, 151.9, 118.7, 92.9, 81.3, 70.5, 64.3, 31.9, 24.5, 19.9, 12.8. HRMS (ESI)m/zcalcd. for $\mathrm{C}_{13} \mathrm{H}_{18} \mathrm{NO}_{5}(\mathrm{M}+\mathrm{H})^{+}:$268.1185, found 268.1190.

\section{(2-(((tert-butyldiphenylsilyl)oxy)methyl)-5-oxo-4-(propan-2-ylidene)tetrahydrofuran-2-}

\section{yl)methyl 4-methylbenzenesulfonate (11)}


To a solution of compound $9(127 \mathrm{mg}, 0.30 \mathrm{mmol})$ in $\mathrm{CH}_{2} \mathrm{Cl}_{2}(2 \mathrm{~mL})$ in a sealed vial triethylamine (606 mg, $6 \mathrm{mmol})$ and $p$-toluenesulfonyl chloride $(114 \mathrm{mg}, 0.6 \mathrm{mmol})$ were added. The reaction mixture was heated at $40{ }^{\circ} \mathrm{C}$ overnight and treated with $\mathrm{HCl} 1 \mathrm{~N}(5 \mathrm{~mL})$. The aqueous layer was extracted with $\mathrm{CH}_{2} \mathrm{Cl}_{2}(3 \times 5 \mathrm{~mL})$. The combined organic layers were washed with $\mathrm{NaHCO}_{3}$ s.s. $(5 \mathrm{~mL})$, NaCls.s. $(5 \mathrm{~mL})$, dried over $\mathrm{Na}_{2} \mathrm{SO}_{4}$ and concentrated under vacuum. The residue was purified by silica gel flash column chromatography hexane:ethyl acetate (9:1) to afford 11 as a white solid (148 mg, 88\%); mp: $44-46{ }^{\circ} \mathrm{C} .{ }^{1} \mathrm{H}$ NMR (400 MHz, $\left.\mathrm{CDCl}_{3}\right) \delta 7.75$ (d, $J=8.3 \mathrm{~Hz}, 2 \mathrm{H}), 7.63-7.56(\mathrm{~m}, 4 \mathrm{H}), 7.47-7.35(\mathrm{~m}, 6 \mathrm{H}), 7.31(\mathrm{~d}, J=8.0 \mathrm{~Hz}, 1 \mathrm{H}), 4.12(\mathrm{~d}, J=$ $10.1 \mathrm{~Hz}, 1 \mathrm{H}), 4.05(\mathrm{~d}, J=10.1 \mathrm{~Hz}, 1 \mathrm{H}), 3.60(\mathrm{~s}, 2 \mathrm{H}), 2.79-2.65(\mathrm{~m}, 2 \mathrm{H}), 2.43(\mathrm{~s}, 3 \mathrm{H}), 2.21(\mathrm{t}, J=$ $2.0 \mathrm{~Hz}, 3 \mathrm{H}), 1.82(\mathrm{~s}, 3 \mathrm{H}), 0.98(\mathrm{~s}, 9 \mathrm{H}) .{ }^{13} \mathrm{C} \mathrm{NMR}\left(101 \mathrm{MHz}, \mathrm{CDCl}_{3}\right) \delta$ 168.5, 151.1, 145.2, $135.5,132.4,132.3,132.1,129.9,128.0,127.8,127.8,118.7,80.3,70.2,66.0,32.0,26.5,24.5$, 21.6, 19.8, 19.1. HRMS (ESI) $m / z$ calcd. for $\mathrm{C}_{32} \mathrm{H}_{39} \mathrm{O}_{6} \mathrm{SSi}(\mathrm{M}+\mathrm{H})^{+}: 579,2237$, found 579,2231.

\section{5-(azidomethyl)-5-((tert-butyldiphenylsilyloxy)methyl)-3-(propan-2-ylidene) dihydrofuran-}

\section{2(3H)-one (12)}

To a solution of tosylate11 $(140 \mathrm{mg}, 0.245 \mathrm{mmol})$ in DMF $(3 \mathrm{~mL})$ in a sealed vial sodium azide (319 mg, $4.9 \mathrm{mmol}$ ) was added. The reaction mixture was heated to $120^{\circ} \mathrm{C}$ for $4 \mathrm{~h}$, then cooled to room temperature and evaporated. The residue was dissolved in $\mathrm{CH}_{2} \mathrm{Cl}_{2}$ and washed with $\mathrm{H}_{2} \mathrm{O}$ and brine, dried over anhydrous $\mathrm{Na}_{2} \mathrm{SO}_{4}$, and concentrated under vacuum. The residue was purified by silica gel flash column chromatography hexane:ethyl acetate (95:5) to afford $\mathbf{1 2}$ (105 mg, 96\%) as a colorless oil. ${ }^{1} \mathrm{H}$ NMR $\left(400 \mathrm{MHz}, \mathrm{CDCl}_{3}\right) \delta$ 7.67-7.62 (m, 4H), 7.47-7.36 (m, 6H), $3.65(\mathrm{AB} \mathrm{m}, 2 \mathrm{H}), 3.52(\mathrm{~d}, J=12.8 \mathrm{~Hz}, 1 \mathrm{H}), 3.46(\mathrm{~d}, J=12.8 \mathrm{~Hz}, 1 \mathrm{H}), 2.73(\mathrm{AB} \mathrm{m}$, 2H), 2.25 (s, 3H), 1.85 (s, 3H), 1.04 (s, 9H). $\left.{ }^{13} \mathrm{C} \mathrm{NMR} \mathrm{(101} \mathrm{MHz,} \mathrm{CDCl}_{3}\right) \delta$ 168.7, 150.7, 135.6, 
135.6, 132.6, 132.5, 129.9, 127.8, 119.3, 81.9, 66.8, 55.1, 32.8, 26.6, 24.5, 19.9, 19.2. HRMS (ESI) $m / z$ calcd. for $\mathrm{C}_{25} \mathrm{H}_{32} \mathrm{~N}_{3} \mathrm{O}_{3} \mathrm{Si}(\mathrm{M}+\mathrm{H})^{+}$: 450,2213, found 450,2218.

\section{5-((tert-butyldiphenylsilyloxy)methyl)-3-(propan-2-ylidene)-5-((4-p-tolyl-1H-1,2,3-triazol-1-} yl)methyl)dihydrofuran-2(3H)-one (13)

4-Ethynyltoluene ( $25 \mathrm{mg}, 26 \mu \mathrm{l}, 0.21 \mathrm{mmol})$ and compound $12(95 \mathrm{mg}, 0.21 \mathrm{mmol})$ were dissolved in $5 \mathrm{~mL}$ of a 1:1 tert $-\mathrm{BuOH} / \mathrm{H}_{2} \mathrm{O}$ mixture. While the mixture was being stirred, sodium ascorbate ( $1 \mathrm{M}$ in $\mathrm{H}_{2} \mathrm{O}, 189 \mu \mathrm{l}, 0.189 \mathrm{mmol}$ ) was added, followed by copper(II) sulfate pentahydrate $(0.3 \mathrm{M}, 280 \mu \mathrm{l}, 0.084 \mathrm{mmol})$. The resulting mixture was stirred at room temperature for $18 \mathrm{~h}$ before diluted with ethyl acetate $(10 \mathrm{~mL})$, saturated with EDTA solution $(0.4 \mathrm{~mL})$ and water $(10 \mathrm{~mL})$. The aqueous layer was extracted with ethyl acetate $(10 \mathrm{~mL} \mathrm{X} \mathrm{3).} \mathrm{The} \mathrm{combined}$ organic layers were dried over $\mathrm{Na}_{2} \mathrm{SO}_{4}$, filtered through a short silica gel column and concentrated in vacuo. The residue was purified by silica gel flash column chromatography hexane:ethyl acetate (9:1) to afford $\mathbf{1 3}(89 \mathrm{mg}, 75 \%)$ as a white solid; mp: $59-62^{\circ} \mathrm{C} .{ }^{1} \mathrm{H}$ NMR $\left(400 \mathrm{MHz}, \mathrm{CDCl}_{3}\right) \delta 7.88(\mathrm{~s}, 1 \mathrm{H}), 7.68(\mathrm{~d}, J=8.3 \mathrm{~Hz}, 2 \mathrm{H}), 7.66-7.63(\mathrm{~m}, 4 \mathrm{H}), 7.46-7.36(\mathrm{~m}$, 6H), $7.23(\mathrm{~d}, J=8.0 \mathrm{~Hz}, 2 \mathrm{H}), 4.72(\mathrm{AB} d, J=14.5 \mathrm{~Hz}, 1 \mathrm{H}), 4.61(\mathrm{AB} \mathrm{d}, J=14.5 \mathrm{~Hz}, 1 \mathrm{H}), 3.72$ (AB d, $J=10.9 \mathrm{~Hz}, 1 \mathrm{H}), 3.65(\mathrm{AB} \mathrm{d}, J=10.8 \mathrm{~Hz}, 1 \mathrm{H}), 2.75(\mathrm{AB} \mathrm{q}, J=16.6 \mathrm{~Hz}, 2 \mathrm{H}), 2.38(\mathrm{~s}$, 3H), 2.06 (s, 3H), $1.74(\mathrm{~s}, 3 \mathrm{H}), 1.08(\mathrm{~s}, 9 \mathrm{H}) .{ }^{13} \mathrm{C} \mathrm{NMR}\left(101 \mathrm{MHz}, \mathrm{CDCl}_{3}\right) \delta$ 168.5, 151.8, 148.3, $138.1,135.6,135.5,132.3,132.2,130.1,129.5,127.9,127.4,125.7,121.0,118.3,81.5,67.2$, 54.0, 32.3, 26.7, 24.5, 21.3, 19.9, 19.2. HRMS (ESI) $m / z$ calcd. for $\mathrm{C}_{34} \mathrm{H}_{40} \mathrm{~N}_{3} \mathrm{O}_{3} \mathrm{Si}(\mathrm{M}+\mathrm{H})^{+}$: 566,2839 , found 566,2847 .

\section{5-(hydroxymethyl)-3-(propan-2-ylidene)-5-((4-p-tolyl-1H-1,2,3-triazol-1-yl)methyl)}

dihydrofuran-2(3H)-one (3) 
To a stirred solution of $\mathbf{1 3}(60 \mathrm{mg}, 0.106 \mathrm{mmol})$ in anhydrous THF (3 mL)

tetrabutylammonium fluoride (TBAF, 1.0 M solution in THF, $106 \mu \mathrm{L}, 0.106 \mathrm{mmol}$ ) was added at $0{ }^{\circ} \mathrm{C}$. After stirring for $1 \mathrm{~h}$, the reaction was evaporated. The residue was purified by column chromatography over silica gel with hexane/ethyl acetate (2:8) as eluent to give the alcohol 3 (28 mg, 80\%) as a white solid; mp: $167-168{ }^{\circ} \mathrm{C} .{ }^{1} \mathrm{H}$ NMR $\left(400 \mathrm{MHz}, \mathrm{CDCl}_{3}\right) \delta 7.88(\mathrm{~s}, 1 \mathrm{H}), 7.69(\mathrm{~d}$, $J=8.0 \mathrm{~Hz}, 2 \mathrm{H}), 7.23(\mathrm{~d}, J=8.0 \mathrm{~Hz}, 2 \mathrm{H}), 4.69(\mathrm{AB} \mathrm{q}, J=14.6 \mathrm{~Hz}, 2 \mathrm{H}), 3.61(\mathrm{dq}, J=12.2 \mathrm{~Hz}$, $6.5 \mathrm{~Hz}, 2 \mathrm{H}), 3.02(\mathrm{t}, J=6.6 \mathrm{~Hz}, 1 \mathrm{H}), 2.84(\mathrm{AB} \mathrm{q}, J=16.5 \mathrm{~Hz}, 2 \mathrm{H}), 2.37(\mathrm{~s}, 3 \mathrm{H}), 2.10(\mathrm{~s}, 3 \mathrm{H})$, 1.80 (s, 3H). ${ }^{13} \mathrm{C}$ NMR (101 MHz, $\left.\mathrm{CDCl}_{3}\right): \delta 168.5,153.5,148.3,138.3,129.5,127.3,125.7$, 121.1, 117.6, 81.4, 65.3, 53.9, 32.5, 24.6, 21.3, 20.0. HRMS (ESI)m/zcalcd. for $\mathrm{C}_{18} \mathrm{H}_{22} \mathrm{~N}_{3} \mathrm{O}_{3}(\mathrm{M}+\mathrm{H})^{+}:$328.1661, found 328.1665.

\section{(E)-5-((benzyloxy)methyl)-5-(((tert-butyldiphenylsilyl)oxy)methyl)-3-(3-isobutyl-5-} methylhexylidene) dihydrofuran-2(3H)-one (14)

Starting from lactone $7^{26}(1.654 \mathrm{~g}, 3.46 \mathrm{mmol}), 3$-isobutyl-5-methylhexanal ${ }^{13}$ (940 mg, 5.45 $\mathrm{mmol}$ ) and following general procedure $\mathrm{A}$, the reaction product was isolated as a 1:1 mixture of E- and Z-isomers respectively. Two fractions were isolated after purification by silica gel flash column chromatography with hexane:ethyl acetate (98:2) as eluent. The first fraction corresponded to the $Z$-isomer (724 mg, 34\%) and the second fraction was the $E$-isomer 14 (763 mg, 35\%). ${ }^{1} \mathrm{H}$ NMR $\left(400 \mathrm{MHz}, \mathrm{CDCl}_{3}\right) \delta 7.64(\mathrm{~d}, J=6.9 \mathrm{~Hz}, 4 \mathrm{H}), 7.46-7.22(\mathrm{~m}, 11 \mathrm{H}), 6.74(\mathrm{~m}$, 1H), $4.53(\mathrm{~s}, 2 \mathrm{H}), 3.73(\mathrm{AB} \mathrm{q}, J=10.7 \mathrm{~Hz}, 2 \mathrm{H}), 3.59(\mathrm{~d}, J=10.1 \mathrm{~Hz}, 1 \mathrm{H}), 3.53(\mathrm{~d}, J=10.1 \mathrm{~Hz}$, $1 \mathrm{H}), 2.82-2.69(\mathrm{AB} \mathrm{m}, 2 \mathrm{H}), 2.10(\mathrm{t}, J=6.2 \mathrm{~Hz}, 2 \mathrm{H}), 1.64-1.60(\mathrm{~m}, 3 \mathrm{H}), 1.14-1.06(\mathrm{~m}, 4 \mathrm{H}), 1.02$ $(\mathrm{s}, 9 \mathrm{H}), 0.85(\mathrm{~d}, J=6.5 \mathrm{~Hz}, 12 \mathrm{H}) .{ }^{13} \mathrm{C} \mathrm{NMR}\left(101 \mathrm{MHz}, \mathrm{CDCl}_{3}\right) \delta 170.3,139.2,137.7,135.6$ $135.6,132.9,132.6,129.8,129.8,128.4,127.9,127.8,127.7,127.6,84.4,73.7,71.9,66.2,43.9$, 
43.8, 34.7, 32.8, 30.3, 26.7, 25.2, 23.0, 22.9, 22.7, 22.6, 19.2. HRMS (ESI) $\mathrm{m} / z \mathrm{calcd}$.

for $\mathrm{C}_{40} \mathrm{H}_{55} \mathrm{O}_{4} \mathrm{Si}(\mathrm{M}+\mathrm{H})^{+}$: 627,3870, found 627,3879 .

\section{(E)-5-((tert-butyldiphenylsilyloxy)methyl)-5-(hydroxymethyl)-3-(3-isobutyl-5-}

\section{methylhexylidene) dihydrofuran-2(3H)-one (15)}

Starting from 14 (644 mg, $1.03 \mathrm{mmol})$ and following general procedure B, 15(490 mg, 89\%) wasobtained as a colorless oil after purification by silica gel flash column chromatography with hexane:ethyl acetate (9:1). ${ }^{1} \mathrm{H}$ NMR (400 MHz, $\left.\mathrm{CDCl}_{3}\right) \delta$ 7.64-7.62 (m, 4H), 7.48-7.35 (m, 6H), $6.76(\mathrm{~m}, 1 \mathrm{H}), 3.77-3.62(\mathrm{~m}, 4 \mathrm{H}), 2.87-2.65(\mathrm{AB} \mathrm{m}, 2 \mathrm{H}), 2.12(\mathrm{t}, J=6.7 \mathrm{~Hz}, 2 \mathrm{H}), 1.93(\mathrm{t}, J=6.8$ $\mathrm{Hz}, 1 \mathrm{H}), 1.75-1.56(\mathrm{~m}, 3 \mathrm{H}), 1.14-1.07(\mathrm{~m}, 4 \mathrm{H}), 1.03(\mathrm{~s}, 9 \mathrm{H}), 0.86(\mathrm{~d}, J=6.5 \mathrm{~Hz}, 12 \mathrm{H}) .{ }^{13} \mathrm{C} \mathrm{NMR}$ $\left(101 \mathrm{MHz}, \mathrm{CDCl}_{3}\right) \delta 170.2,140.0,135.6,135.6,132.7,132.5,130.0,129.9,127.8,127.7,85.1$, $66.0,65.3,43.9,43.8,34.8,32.8,29.7,26.7,25.2,23.0,22.9,22.7,22.6,19.2$. HRMS (ESI) $m / z$ calcd. forC ${ }_{33} \mathrm{H}_{48} \mathrm{O}_{4} \mathrm{SiNa}(\mathrm{M}+\mathrm{Na})^{+}: 559,3220$, found 559,3224 .

\section{(E)-(2-((tert-butyldiphenylsilyloxy)methyl)-4-(3-isobutyl-5-methylhexylidene)-5-oxotetra}

\section{hydro furan-2-yl)methyl 4-methylbenzenesulfonate (16)}

To a solution of 15 (474 mg, $0.88 \mathrm{mmol}$ ) in pyridine $(4 \mathrm{~mL}) p$-toluenesulfonyl chloride (421 $\mathrm{mg}, 2.2 \mathrm{mmol}$ ) was added. The reaction mixture was heated to $90{ }^{\circ} \mathrm{C}$ overnight and treated with $\mathrm{HCl} 1 \mathrm{~N}(8 \mathrm{~mL})$. The aqueous layer was extracted with $\mathrm{CH}_{2} \mathrm{Cl}_{2}(3 \times 10 \mathrm{~mL})$. The combined organic layers were washed with $\mathrm{NaHCO}_{3}$ s.s. $(10 \mathrm{~mL})$, NaCls.s. $(10 \mathrm{~mL})$, dried over $\mathrm{Na}_{2} \mathrm{SO}_{4}$ and concentrated under vacuum. The residue was purified by silica gel flash column chromatography with hexane:ethyl acetate (98:2) to afford $\mathbf{1 6}$ (423 $\mathrm{mg}, 90 \%$ ) as a white solid; mp: $135-136^{\circ} \mathrm{C}$. ${ }^{1} \mathrm{H}$ NMR (400 MHz, $\left.\mathrm{CDCl}_{3}\right) \delta 7.74(\mathrm{~d}, J=8.1 \mathrm{~Hz}, 2 \mathrm{H}), 7.63-7.55(\mathrm{~m}, 4 \mathrm{H}), 7.48-7.34(\mathrm{~m}, 6 \mathrm{H})$, $7.31(\mathrm{~d}, J=8.1 \mathrm{~Hz}, 1 \mathrm{H}), 6.74(\mathrm{~m}, 1 \mathrm{H}), 4.14(\mathrm{~d}, J=10.2 \mathrm{~Hz}, 1 \mathrm{H}), 4.06(\mathrm{~d}, J=10.2 \mathrm{~Hz}, 1 \mathrm{H}), 3.62$ 
(s, 2H), 2.79-2.65 (m, 2H), $2.43(\mathrm{~s}, 3 \mathrm{H}), 2.08(\mathrm{t}, J=6.4 \mathrm{~Hz}, 2 \mathrm{H}), 1.73-1.55(\mathrm{~m}, 3 \mathrm{H}), 1.15-1.02$

(m, 4H), $0.98(\mathrm{~s}, 9 \mathrm{H}), 0.86(\mathrm{~m}, 12 \mathrm{H}) .{ }^{13} \mathrm{C} \mathrm{NMR}\left(101 \mathrm{MHz}, \mathrm{CDCl}_{3}\right) \delta 169.2,145.2,140.9,135.5$,

$132.3,132.2,130.0,130.0,128.0,127.9,126.3,82.1,70.1,65.9,43.9,43.8,34.9,32.8,30.0$,

26.6, 25.2, 22.9, 22.9, 22.6, 22.6, 21.6, 19.2. HRMS (ESI) $m / z$ calcd. for $\mathrm{C}_{40} \mathrm{H}_{55} \mathrm{O}_{6} \mathrm{SSi}(\mathrm{M}+\mathrm{H})^{+}$:

691,3489 , found 691,3475 .

\section{(E)-5-(azidomethyl)-5-((tert-butyldiphenylsilyloxy)methyl)-3-(3-isobutyl-5-methylhexylide}

ne) dihydrofuran-2(3H)-one (17)

To a solution of tosylate 16 (400 $\mathrm{mg}, 0.58 \mathrm{mmol})$ in DMF (3 mL) was added sodium azide (754 $\mathrm{mg}, 11.6 \mathrm{mmol})$. The reaction mixture was heated to $90{ }^{\circ} \mathrm{C}$ for $72 \mathrm{~h}$, then cooled to room temperature and evaporated. The residue was dissolved in $\mathrm{CH}_{2} \mathrm{Cl}_{2}$ and washed with $\mathrm{H}_{2} \mathrm{O}$ and brine, dried over anhydrous $\mathrm{Na}_{2} \mathrm{SO}_{4}$, and concentrated under vacuum. The residue was purified by silica gel flash column chromatography hexane:ethyl acetate (99:1) to afford $\mathbf{1 7}$ (235 mg, 72 \%) as a colorless syrup. ${ }^{1} \mathrm{H}$ NMR $\left(300 \mathrm{MHz}, \mathrm{CDCl}_{3}\right) \delta$ 7.66-7.61 (m, 4H), 7.54-7.40 (m, 6H), $6.78(\mathrm{~m}, 1 \mathrm{H}), 3.75-3.67(\mathrm{mAB}, 2 \mathrm{H}), 3.54(\mathrm{AB} \mathrm{d}, J=12.8 \mathrm{~Hz}, 1 \mathrm{H}), 3.47(\mathrm{AB} \mathrm{d}, J=12.8 \mathrm{~Hz}, 1 \mathrm{H})$, $2.70(\mathrm{AB} \mathrm{m}, 2 \mathrm{H}), 2.11(\mathrm{t}, J=6.7 \mathrm{~Hz}, 2 \mathrm{H}), 1.75-1.56(\mathrm{~m}, 3 \mathrm{H}), 1.17-1.04(\mathrm{~m}, 4 \mathrm{H}), 1.04(\mathrm{~s}$, 9H),0.86 (m, 12H). ${ }^{13} \mathrm{C}$ NMR $\left(75 \mathrm{MHz}, \mathrm{CDCl}_{3}\right) \delta 169.5,140.5,135.6,135.6,132.5,132.3$, $130.0,127.9,126.9,83.7,66.5,55.1,43.9,43.8,34.8,32.8,30.7,26.7,25.2,23.0,22.9,22.7$, 22.6, 19.2. HRMS (ESI) $m / z$ calcd. forC ${ }_{33} \mathrm{H}_{47} \mathrm{~N}_{3} \mathrm{O}_{3} \mathrm{SiNa}(\mathrm{M}+\mathrm{H})^{+}:$584,3284, found 584,3290.

\section{(E)-5-((tert-butyldiphenylsilyloxy)methyl)-3-(3-isobutyl-5-methylhexylidene)-5-((4-p-tolyl-} 1H-1,2,3-triazol-1-yl)methyl)dihydrofuran-2(3H)-one (18)

4-Ethynyltoluene (23 mg, $25 \mu 1,0.20 \mathrm{mmol})$ and 17 (102 mg, $0.18 \mathrm{mmol})$ were dissolved in 4 $\mathrm{mL}$ of a $1: 1$ tert $-\mathrm{BuOH} / \mathrm{H}_{2} \mathrm{O}$ mixture. While the mixture was being stirred, sodium ascorbate $(0.3$ 
$\mathrm{M}$ in $\left.\mathrm{H}_{2} \mathrm{O}, 480 \mu \mathrm{l}, 0.144 \mathrm{mmol}\right)$ was added, followed by copper(II) sulfate pentahydrate $(0.3 \mathrm{M}$, $240 \mu \mathrm{l}, 0.072 \mathrm{mmol})$. The resulting mixture was stirred at room temperature for $2 \mathrm{~h}$ before diluted with ethyl acetate $(10 \mathrm{~mL})$, saturated with EDTA solution $(0.4 \mathrm{~mL})$ and water $(10 \mathrm{~mL})$. The aqueous layer was extracted with ethyl acetate $(3 \times 10 \mathrm{~mL})$. The combined organic layers were dried over $\mathrm{Na}_{2} \mathrm{SO}_{4}$, filtered through a short silica gel column and concentrated in vacuo. The residue was purified by silica gel flash column chromatography hexane:ethyl acetate (93:7) to afford $18(95 \mathrm{mg}, 77 \%)$ as a colorless syrup. ${ }^{1} \mathrm{H}$ NMR $\left(300 \mathrm{MHz}, \mathrm{CDCl}_{3}\right) \delta 7.85(\mathrm{~s}, 1 \mathrm{H}), 7.67$ $(\mathrm{d}, J=8.1 \mathrm{~Hz}, 2 \mathrm{H}), 7.66-7.61(\mathrm{~m}, 4 \mathrm{H}), 7.49-7.34(\mathrm{~m}, 6 \mathrm{H}), 7.22(\mathrm{~d}, J=8.0 \mathrm{~Hz}, 2 \mathrm{H}), 6.62(\mathrm{~m}$, $1 \mathrm{H}), 4.74(\mathrm{AB} \mathrm{d}, J=14.5 \mathrm{~Hz}, 1 \mathrm{H}), 4.64(\mathrm{AB} \mathrm{d}, J=14.5 \mathrm{~Hz}, 1 \mathrm{H}), 3.73(\mathrm{AB} \mathrm{d}, J=11 \mathrm{~Hz}, 1 \mathrm{H})$, $3.65(\mathrm{AB} \mathrm{q}, J=11 \mathrm{~Hz}, 1 \mathrm{H}), 2.82(\mathrm{AB} \mathrm{q}, J=17.6 \mathrm{~Hz}, 1 \mathrm{H}), 2.71(\mathrm{AB} \mathrm{q}, J=17.6 \mathrm{~Hz}, 1 \mathrm{H}), 2.38(\mathrm{~s}$, $3 \mathrm{H}), 1.99(\mathrm{t}, J=6.6 \mathrm{~Hz}, 2 \mathrm{H}), 1.67-1.46(\mathrm{~m}, 3 \mathrm{H}), 1.13-0.93(\mathrm{~m}, 4 \mathrm{H}), 1.08(\mathrm{~s}, 9 \mathrm{H}), 0.81(\mathrm{~d}, J=6.5$ $\mathrm{Hz}, 12 \mathrm{H}) .{ }^{13} \mathrm{C} \mathrm{NMR}\left(75 \mathrm{MHz}, \mathrm{CDCl}_{3}\right) \delta 169.2,148.4,141.5,138.1,135.6,135.5,132.2,132.1$, $130.1,129.5,127.9,127.4,125.8,125.7,120.8,83.1,66.9,53.9,43.8,34.8,32.7,30.2,29.7$, 26.7, 25.1, 22.9, 22.6, 22.6, 21.3, 19.2. HRMS (ESI) $m / z$ calcd. for $\mathrm{C}_{42} \mathrm{H}_{56} \mathrm{~N}_{3} \mathrm{O}_{3} \mathrm{Si}(\mathrm{M}+\mathrm{H})^{+}$: 678,4091 , found 678,4121 .

\section{(E)-5-(hydroxymethyl)-3-(3-isobutyl-5-methylhexylidene)-5-((4-p-tolyl-1H-1,2,3-triazol-1-}

\section{yl)methyl)dihydrofuran-2(3H)-one (4)}

To a stirred solution of $18(79 \mathrm{mg}, 0.12 \mathrm{mmol})$ in anhydrous THF (3 mL) tetrabutylammonium fluoride $\left(1.0 \mathrm{M}\right.$ solution in THF, $120 \mu \mathrm{L}, 0.12 \mathrm{mmol}$ ) was added at $0{ }^{\circ} \mathrm{C}$. After stirring for $1 \mathrm{~h}$, the reaction was evaporated. The residue was purified by column chromatography over silica gel with hexane/ethyl acetate (75:25) as eluent to afford 4 (31 mg, 60\%) as a white solid; mp: 155$156{ }^{\circ} \mathrm{C} .{ }^{1} \mathrm{H} \mathrm{NMR}\left(400 \mathrm{MHz}, \mathrm{CDCl}_{3}\right) \delta 7.88(\mathrm{~s}, 1 \mathrm{H}), 7.69(\mathrm{~d}, J=7.7 \mathrm{~Hz}, 2 \mathrm{H}), 7.23(\mathrm{~d}, J=7.7 \mathrm{~Hz}$, 2H), $6.72(\mathrm{~m}, 1 \mathrm{H}), 4.79(\mathrm{AB} \mathrm{d}, J=14.6 \mathrm{~Hz}, 1 \mathrm{H}), 4.63(\mathrm{AB} \mathrm{d}, J=14.6 \mathrm{~Hz}, 1 \mathrm{H}), 3.70-3.45(\mathrm{~m}$, 
2H), $2.93(\mathrm{t}, J=6.3 \mathrm{~Hz}, 1 \mathrm{H}), 2.83(\mathrm{~s}, 2 \mathrm{H}), 2.37(\mathrm{~s}, 3 \mathrm{H}), 2.07(\mathrm{~m}, 2 \mathrm{H}), 1.71-1.49(\mathrm{~m}, 3 \mathrm{H}), 1.15-$

$0.93(\mathrm{~m}, 4 \mathrm{H}), 0.83(\mathrm{~d}, J=5.9 \mathrm{~Hz}, 12 \mathrm{H}) .{ }^{13} \mathrm{C} \mathrm{NMR}\left(101 \mathrm{MHz}, \mathrm{CDCl}_{3}\right) \delta$ 169.1, 148.4, 142.7,

$138.3,129.5,127.2,125.7,125.3,121.0,83.10,65.0,53.7,43.9,34.9,32.8,30.6,25.2,22.9$,

22.9, 22.6, 22.5, 21.3. HRMS (ESI) $m / z$ calcd. for $\mathrm{C}_{26} \mathrm{H}_{38} \mathrm{~N}_{3} \mathrm{O}_{3}(\mathrm{M}+\mathrm{H})^{+}: 440.2913$, found 440.2926.

\section{(E)-5-((benzyloxy)methyl)-5-(hydroxymethyl)-3-(3-isobutyl-5-}

methylhexylidene) dihydrofuran-2(3H)-one (21)

Compound 21 was synthesized following a procedure described in the reference 33.33

Starting from lactone $\mathbf{1 9}^{32}(2.52 \mathrm{~g}, 7.4 \mathrm{mmol})$, 3-isobutyl-5-methylhexanal ${ }^{13}$ (1.9 g, 11.41

mmol) and following general procedure A, the reaction product was isolated as a 1:1 mixture of E- and Z-isomers respectively. Two fractions were isolated after purification by silica gel flash column chromatography with hexane:ethyl acetate (98:2) as eluent. The first fraction corresponded to the $Z$-isomer ( $1.23 \mathrm{~g}, 34 \%)$ and the second fraction the $E$-isomer $20(1.27 \mathrm{~g}$, $35 \%)$. Recorded spectra perfectly matched the published results. ${ }^{1} \mathrm{H}$ NMR $\left(400 \mathrm{MHz}, \mathrm{CDCl}_{3}\right) \delta$ 7.36-7.26 (m, $5 \mathrm{H}), 6.81(\mathrm{~s}, 4 \mathrm{H}), 6.82-6.76(\mathrm{~m}, 1 \mathrm{H}), 4.58(\mathrm{AB} \mathrm{q}, J=12.3 \mathrm{~Hz}, 2 \mathrm{H}), 4.03$ (AB q, $J$ $=9.8,26.6 \mathrm{~Hz}, 2 \mathrm{H}), 3.76(\mathrm{~s}, 3 \mathrm{H}), 3.66(\mathrm{AB} \mathrm{q}, J=10.3,23.7 \mathrm{~Hz}, 2 \mathrm{H}), 2.92-2.77(\mathrm{AB} \mathrm{m}, 2 \mathrm{H})$, $2.13(\mathrm{t}, J=11.6 \mathrm{~Hz}, 2 \mathrm{H}), 1.76-1.58(\mathrm{~m}, 3 \mathrm{H}), 1.14-1.06(\mathrm{~m}, 4 \mathrm{H}), 0.85(\mathrm{~m}, 12 \mathrm{H})$.

Starting from $E$-isomer $\mathbf{2 0}(1.26 \mathrm{~g}, 2.55 \mathrm{mmol})$ and following general procedure $\mathrm{C}, \mathbf{2 1}$ was obtained as a colorless oil ( $746 \mathrm{mg}, 75 \%$ yield). Its spectrum data perfectly matched with published results. ${ }^{1} \mathrm{H}$ NMR (400 MHz, $\left.\mathrm{CDCl}_{3}\right) \delta$ 7.40-7.26 (m, 5H), 6.82-6.73 (m, 1H), 4.56 (m, $2 \mathrm{H}), 3.84-3.64(\mathrm{~m}, 2 \mathrm{H}), 3.57$ (AB q, $J=9.9,28.0 \mathrm{~Hz}, 2 \mathrm{H}), 2.83-2.65(\mathrm{~m}, 2 \mathrm{H}), 2.19-2.07$ (m, $3 \mathrm{H}), 1.77-1.55(\mathrm{~m}, 3 \mathrm{H}), 1.15-1.05(\mathrm{~m}, 4 \mathrm{H}), 0.84-0.86(\mathrm{~m}, 12 \mathrm{H})$. 
(E)-5-((benzyloxy)methyl)-5-(iodomethyl)-3-(3-isobutyl-5-methylhexylidene) dihydrofuran2(3H)-one (22)

A solution of $21^{33}(128 \mathrm{mg}, 0.33 \mathrm{mmol})$ in toluene $(6 \mathrm{~mL})$ was treated with triphenylphosphine (173 mg, $0.66 \mathrm{mmol})$, imidazole (67 mg, $0.99 \mathrm{mmol})$, and iodine (126 mg, $0.5 \mathrm{mmol})$. The mixture was heated at $90{ }^{\circ} \mathrm{C}$ for $1 \mathrm{~h}$ and after reaching room temperature, was poured into a saturated solution of $\mathrm{NaHCO}_{3}$. Excess of triphenylphosphine was destroyed by the addition of iodine until the iodine coloration persisted in the organic layer. The organic layer was washed with $\mathrm{Na}_{2} \mathrm{~S}_{2} \mathrm{O}_{3}(10 \%, 5 \mathrm{ml})$ and brine, dried over $\left(\mathrm{MgSO}_{4}\right)$, filtered, and concentrated in vacuo. The residue was purified on silica gel (hexanes:ethyl acetate, 98:2) to give $22(146 \mathrm{mg}, 89 \%)$ as a colorless syrup. ${ }^{1} \mathrm{H}$ NMR $\left(400 \mathrm{MHz}, \mathrm{CDCl}_{3}\right) \delta$ 7.38-7.27(m, 5H), 6.82-6.75 (m, 1H), $4.58(\mathrm{~s}$, 2H), $3.68(\mathrm{AB} \mathrm{d}, J=10.0 \mathrm{~Hz}, 1 \mathrm{H}), 3.63(\mathrm{AB} \mathrm{d}, J=10.0 \mathrm{~Hz}, 1 \mathrm{H}), 3.49(\mathrm{AB} \mathrm{d}, J=10.8 \mathrm{~Hz}, 1 \mathrm{H})$, $3.43(\mathrm{AB} \mathrm{d}, J=10.8 \mathrm{~Hz}, 1 \mathrm{H}), 2.92-2.72(\mathrm{AB} \mathrm{m}, 2 \mathrm{H}), 2.15-2.08(\mathrm{~m}, 2 \mathrm{H}), 1.76-1.67(\mathrm{~m}, 1 \mathrm{H})$, 1.66-1.58 (m, 2H), 1.17-1.02 (m, 4H), $0.85(\mathrm{~m}, 12 \mathrm{H}) .{ }^{13} \mathrm{C} \mathrm{NMR}\left(101 \mathrm{MHz}, \mathrm{CDCl}_{3}\right) \delta 169.3$, $140.8,137.3,128.5,127.9,127.7,127.1,81.5,73.8,73.1,43.9,43.9,34.8,34.1,32.8,25.2,23.0$, 22.9, 22.6, 11.0. HRMS (ESI) $m / z$ calcd. for $\mathrm{C}_{24} \mathrm{H}_{36} \mathrm{IO}_{3}(\mathrm{M}+\mathrm{H})^{+}:$499, 1709, found499, 1703 .

\section{(E)-5-((benzyloxy)methyl)-3-(3-isobutyl-5-methylhexylidene)-5-(((5-methylisoxazol-3-} yl)oxy)methyl)dihydrofuran-2(3H)-one (23)

From 21: A solution of triphenylphosphine (325 mg, $1.24 \mathrm{mmol}), 21$ (160 mg, $0.41 \mathrm{mmol}$ ) and 5-methylisoxazol-3-ol (62 mg, $0.62 \mathrm{mmol})$ in anhydrous tetrahydrofuran $(5 \mathrm{~mL})$ was treated with diisopropyl azodicarboxylate $(243 \mu \mathrm{L}, 1.24 \mathrm{mmol})$ and stirred at room temperature overnight. The reaction mixture was evaporated and the residue was purified by flash chromatography using hexane:ethyl acetate (95:5) as eluent to afford $\mathbf{2 3}(70 \mathrm{mg}, 37 \%)$ as a colorless syrup. ${ }^{1} \mathrm{H}$ 
NMR (400 MHz, $\left.\mathrm{CDCl}_{3}\right) \delta$ 7.37-7.25 (m, 5H), 6.83-6.73 (m, 1H), $5.59(\mathrm{~s}, 1 \mathrm{H}), 4.57(\mathrm{~s}, 2 \mathrm{H})$, 4.41-4.32 (AB q, 2H), $3.65(\mathrm{AB} \mathrm{d}, J=13.4 \mathrm{~Hz}, 1 \mathrm{H}), 3.57(\mathrm{AB} \mathrm{d}, J=13.4 \mathrm{~Hz}, 1 \mathrm{H}), 2.92-2.70$ (AB m, 2H), $2.32(\mathrm{~s}, 3 \mathrm{H}), 2.11(\mathrm{t}, J=8.0 \mathrm{~Hz}, 2 \mathrm{H}), 1.74-1.54(\mathrm{~m}, 3 \mathrm{H}), 1.15-1.02(\mathrm{~m}, 4 \mathrm{H}), 0.85$ $(\mathrm{d}, J=6.5 \mathrm{~Hz}, 12 \mathrm{H}) .{ }^{13} \mathrm{C} \mathrm{NMR}\left(101 \mathrm{MHz}, \mathrm{CDCl}_{3}\right) \delta 171.6,170.7,169.7,140.3,137.4,128.4$, $127.8,127.6,126.8,92.9,82.2,73.7,71.5,70.8,43.7,34.7,32.7,30.5,25.2,22.9,22.6,12.9$. HRMS (ESI) $m / z$ calcd. for $\mathrm{C}_{28} \mathrm{H}_{39} \mathrm{NO}_{5} \mathrm{Na}(\mathrm{M}+\mathrm{H})^{+}:$492,2726, found 492,2742.

From 22: A solution of iodine $22(50 \mathrm{mg}, 0.10 \mathrm{mmol}), \mathrm{K}_{2} \mathrm{CO}_{3}(140 \mathrm{mg}, 1 \mathrm{mmol})$ and 5methylisoxazol-3-ol (99 mg, $1 \mathrm{mmol})$ in DMF $(0.5 \mathrm{~mL})$ was stirred at $140{ }^{\circ} \mathrm{C}$ for $4 \mathrm{~h}$ in a sealed vial. Afterwards, the reaction was cooled to room temperature, diluted with $\mathrm{CH}_{2} \mathrm{Cl}_{2}(3 \mathrm{ml})$ and washed with $\mathrm{NaOH}(5 \%)$ and brine. The organic phase was dried over anhydrous $\mathrm{Na}_{2} \mathrm{SO}_{4}$, filtered and concentrated under vacuum. The residue was purified by silica gel flash column chromatography hexane:ethyl acetate (95:5) to afford $\mathbf{2 3}(29 \mathrm{mg}, 62 \%)$.

\section{(E)-5-(hydroxymethyl)-3-(3-isobutyl-5-methylhexylidene)-5-(((5-methylisoxazol-3-}

\section{yl)oxy)methyl)dihydrofuran-2(3H)-one $(2,10 B 12)$}

Starting from $22(26 \mathrm{mg}, 0.055 \mathrm{mmol})$ and following general procedure B, compound 2 (10B12) was obtained as a white solid (14 mg, 67\%); mp: 81-82 ${ }^{\circ} \mathrm{C} .{ }^{1} \mathrm{H}$ NMR $(400 \mathrm{MHz}$, $\left.\mathrm{CDCl}_{3}\right) \delta 6.80(\mathrm{~m}, 1 \mathrm{H}), 5.63(\mathrm{~s}, 1 \mathrm{H}), 4.40(\mathrm{AB} \mathrm{d}, J=11.3 \mathrm{~Hz}, 1 \mathrm{H}), 4.32(\mathrm{AB} \mathrm{d}, J=11.3 \mathrm{~Hz}$, $1 \mathrm{H}), 3.78-3.67(\mathrm{~m}, 2 \mathrm{H}), 2.85(\mathrm{AB} \mathrm{d}, J=17.1 \mathrm{~Hz}, 1 \mathrm{H}), 2.73(\mathrm{AB} \mathrm{d}, J=17.1 \mathrm{~Hz}, 1 \mathrm{H}), 2.71(\mathrm{t}, J=$ $6.9 \mathrm{~Hz}, 1 \mathrm{H}), 2.32(\mathrm{~s}, 3 \mathrm{H}), 2.13(\mathrm{t}, J=6.5 \mathrm{~Hz}, 2 \mathrm{H}), 1.76-1.55(\mathrm{~m}, 3 \mathrm{H}), 1.15-1.03(\mathrm{~m}, 4 \mathrm{H}), 0.85(\mathrm{~d}$, $J=6.5 \mathrm{~Hz}, 12 \mathrm{H}) .{ }^{13} \mathrm{C} \mathrm{NMR}\left(101 \mathrm{MHz}, \mathrm{CDCl}_{3}\right) \delta 171.8,171.0,169.7,141.2,126.5,92.9,83.1$, 70.5, 64.4, 43.8, 34.8, 32.8, 30.0, 25.2, 25.2, 22.9, 22.6, 12.9. HRMS (ESI) $m / z$ calcd. for $\mathrm{C}_{21} \mathrm{H}_{34} \mathrm{NO}_{5}(\mathrm{M}+\mathrm{H})^{+}:$380.2437, found 380.2451. 


\section{5-((benzyloxy)methyl)-5-(hydroxymethyl)-3-(propan-2-ylidene)dihydrofuran-2(3H)-one (25)}

Compound $\mathbf{2 5}$ was synthesized following a procedure described in reference $39 .{ }^{37}$

Starting from lactone $19(3.51 \mathrm{~g}, 10.24 \mathrm{mmol})$, acetone $(1.78 \mathrm{~g}, 30.72 \mathrm{mmol})$ and following general procedure A, 24 (3.5 g, 90\%) was obtained as a white solid; mp $77-79^{\circ} \mathrm{C}$. Its spectrum data perfectly matched with published results. ${ }^{1} \mathrm{H} \mathrm{NMR}\left(300 \mathrm{MHz}, \mathrm{CDCl}_{3}\right) \delta$ 7.37-7.26 (m, 5H), 6.87 (s, 4H), 4.65 (AB q, $J=12.3 \mathrm{~Hz}, 2 \mathrm{H}), 4.11$ (AB q, $J=9.6,2 \mathrm{H}), 3.82$ (s, 3H), 3.71 (AB q, $J=$ $10.2,2 \mathrm{H}), 2.97-2.84(\mathrm{AB} \mathrm{m}, 2 \mathrm{H}), 2.33(\mathrm{t}, J=2.1 \mathrm{~Hz}, 2 \mathrm{H}), 1.92(\mathrm{~s}, 3 \mathrm{H})$.

Starting from 24 ( $890 \mathrm{mg}, 2.32 \mathrm{mmol}$ ) and following general procedure C, 25 was obtained as a colorless oil (586 mg, 92\%). Its spectrum data perfectly matched with published results. ${ }^{1} \mathrm{H}$ NMR (400 MHz, $\left.\mathrm{CDCl}_{3}\right) \delta$ 7.40-7.26 (m, 5H), $4.56(\mathrm{AB} \mathrm{q}, J=12.1,2 \mathrm{H}), 3.70(\mathrm{AB} \mathrm{dq}, J=6.6$, 12.1, 34.5 Hz, 2H), 3.55 (AB q, $J=9.9,27.6 \mathrm{~Hz}, 2 \mathrm{H}), 2.82-2.67$ (m, 2H), 2.25 (m, 4H), 1.86 (s, $3 \mathrm{H})$.

\section{5-((benzyloxy)methyl)-5-(iodomethyl)-3-(propan-2-ylidene)dihydrofuran-2(3H)-one (26)}

A solution of $\mathbf{2 5}(200 \mathrm{mg}, 0.73 \mathrm{mmol})$ in toluene $(13 \mathrm{~mL})$ was treated with triphenylphosphine (380 mg, $1.45 \mathrm{mmol})$, imidazole (148 mg, $2.18 \mathrm{mmol})$, and iodine (277 mg, $1.1 \mathrm{mmol})$. The mixture was heated at $90^{\circ} \mathrm{C}$ for $2 \mathrm{~h}$ and after reaching room temperature, was poured into a saturated solution of $\mathrm{NaHCO}_{3}$. Excess triphenylphosphine was destroyed by the addition of iodine until the iodine coloration persisted in the organic layer. The organic layer was washed with $\mathrm{Na}_{2} \mathrm{~S}_{2} \mathrm{O}_{3}(10 \%, 5 \mathrm{ml})$ and brine, dried over $\left(\mathrm{MgSO}_{4}\right)$, filtered, and concentrated in vacuo. The residue was purified on silica gel (hexanes:ethyl acetate, 9:1) to give $\mathbf{2 6}(266 \mathrm{mg}, 95 \%$ ) as a colorless oil. ${ }^{1} \mathrm{H}$ NMR (400 MHz, $\mathrm{CDCl}_{3}$ ) $\delta$ 7.38-7.27(m, 5H), 4.64-4.53 (AB m, 2H), 3.68-3.60 
(AB m, 2H), 3.49 (AB d, $J=14.2 \mathrm{~Hz}, 1 \mathrm{H}$ ), 3.40 (AB d, $J=14.2 \mathrm{~Hz}, 1 \mathrm{H}), 2.91-2.73$ (AB m, 2H), $2.26(\mathrm{t}, J=2.8 \mathrm{~Hz}, 3 \mathrm{H}), 1.86(\mathrm{~s}, 3 \mathrm{H}) .{ }^{13} \mathrm{C} \mathrm{NMR}\left(101 \mathrm{MHz}, \mathrm{CDCl}_{3}\right) \delta$ 168.6, 151.6, 137.4, 128.4, $127.8,127.7,119.3,79.7,73.7,73.2,35.9,24.6,20.0,11.4$. HRMS (ESI) $m / z$ calcd. for $\mathrm{C}_{16} \mathrm{H}_{20} \mathrm{IO}_{3}(\mathrm{M}+\mathrm{H})^{+}:$387.0457, found387.0468.

\section{5-((benzyloxy)methyl)-5-((5-phenyl-2H-tetrazol-2-yl)methyl)-3-(propan-2-}

ylidene) dihydrofuran-2(3H)-one (27)

A solution of $\mathbf{2 6}$ (111 mg, $0.28 \mathrm{mmol}), \mathrm{K}_{2} \mathrm{CO}_{3}(386 \mathrm{mg}, 2.8 \mathrm{mmol})$ and 5-phenyl- $1 \mathrm{H}$ tetrazole ${ }^{36}(420 \mathrm{mg}, 2.8 \mathrm{mmol})$ in DMF $(1 \mathrm{~mL})$ was stirred at $120^{\circ} \mathrm{C}$ overnight in a sealed vial. Then cooled to room temperature, diluted with $\mathrm{CH}_{2} \mathrm{Cl}_{2}(3 \mathrm{ml})$ and filtered. The organic phase was washed with brine, dried over anhydrous $\mathrm{Na}_{2} \mathrm{SO}_{4}$, filtered and concentrated under vacuum. The residue was purified by silica gel flash column chromatography hexane:ethyl acetate (92:8) to afford 27 (84 mg, $74 \%$ ) as a white solid; mp: $87-88{ }^{\circ} \mathrm{C} .{ }^{1} \mathrm{H}$ NMR $\left(400 \mathrm{MHz}, \mathrm{CDCl}_{3}\right) \delta 8.15-$ $8.08(\mathrm{~m}, 2 \mathrm{H}), 7.52-7.45(\mathrm{~m}, 3 \mathrm{H}), 7.38-7.27(\mathrm{~m}, 5 \mathrm{H}), 5.00(\mathrm{AB} \mathrm{d}, J=14.0 \mathrm{~Hz}, 1 \mathrm{H}), 4.92(\mathrm{AB} \mathrm{d}, J$ $=14.0 \mathrm{~Hz}, 1 \mathrm{H}), 4.67(\mathrm{AB} \mathrm{d}, J=11.9 \mathrm{~Hz}, 2 \mathrm{H}), 4.61(\mathrm{AB} \mathrm{d}, J=11.9 \mathrm{~Hz}, 1 \mathrm{H}), 3.68(\mathrm{AB} \mathrm{d}, J=$ $10.1 \mathrm{~Hz}, 1 \mathrm{H}), 3.60$ (AB d, $J=10.1 \mathrm{~Hz}, 1 \mathrm{H}), 2.95(\mathrm{~d}, J=16.6 \mathrm{~Hz}, 1 \mathrm{H}), 2.75(\mathrm{~d}, J=16.6 \mathrm{~Hz}, 1 \mathrm{H})$, 2.04 (s, 3H), $1.72(\mathrm{~s}, 3 \mathrm{H}) .{ }^{13} \mathrm{C}$ NMR (101 MHz, $\left.\mathrm{CDCl}_{3}\right) \delta 168.0,165.4,152.0,137.2,130.5$, $128.9,128.5,128.0,127.8,127.0,126.9,117.6,79.9,73.8,72.7,56.9,33.4,24.4,19.8 . \mathrm{HRMS}$ (ESI) $m / z$ calcd. for $\mathrm{C}_{23} \mathrm{H}_{25} \mathrm{~N}_{4} \mathrm{O}_{3}(\mathrm{M}+\mathrm{H})^{+}: 405,1927$, found 405,1936.

\section{5-(hydroxymethyl)-5-((5-phenyl-2H-tetrazol-2-yl)methyl)-3-(propan-2-ylidene) dihydrofuran-} 2(3H)-one (5)

Starting from 27 (78 $\mathrm{mg}, 0.194 \mathrm{mmol})$ and following general procedure B, $\mathbf{5}$ was obtained as a white solid (55 mg, 90\%); mp: 154-155 ${ }^{\circ} \mathrm{C} .{ }^{1} \mathrm{H}$ NMR (400 MHz, $\left.\mathrm{CDCl}_{3}\right) \delta$ 8.15-8.08 (m, 2H), 
$7.52-7.45(\mathrm{~m}, 3 \mathrm{H}), 4.96(\mathrm{~s}, 2 \mathrm{H}), 3.79(\mathrm{~d}, J=6.4 \mathrm{~Hz}, 2 \mathrm{H}), 2.95(\mathrm{~d}, J=16.4 \mathrm{~Hz}, 1 \mathrm{H}), 2.73(\mathrm{~d}, J=$ $16.4 \mathrm{~Hz}, 1 \mathrm{H}), 2.74-2.68(\mathrm{~m}, 1 \mathrm{H}), 2.07$ (s, 3H), 1.76 (s, 3H). ${ }^{13} \mathrm{C} \mathrm{NMR}\left(101 \mathrm{MHz}, \mathrm{CDCl}_{3}\right) \delta 168.1$, $165.5,152.9,130.6,128.9,126.9,126.8,117.5,81.0,65.8,56.3,32.4,24.5$, 19.9.HRMS (ESI) $m / z$ calcd. for $\mathrm{C}_{16} \mathrm{H}_{19} \mathrm{~N}_{4} \mathrm{O}_{3}(\mathrm{M}+\mathrm{H})^{+}:$315.1457, found 315.1467.

\section{(E)-5-((benzyloxy) methyl)-3-(3-isobutyl-5-methylhexylidene)-5-((5-phenyl-2H-tetrazol-2-}

\section{yl)methyl)dihydrofuran-2(3H)-one (29)}

A solution of triphenylphosphine $(226 \mathrm{mg}, 0.85 \mathrm{mmol})$, lactone $21(110 \mathrm{mg}, 0.29 \mathrm{mmol})$ and 5-phenyl-1H-tetrazole $(124 \mathrm{mg}, 0.85 \mathrm{mmol})$ in anhydrous THF $(6 \mathrm{~mL})$ was treated with DIAD $(168 \mu \mathrm{L}, 0.85 \mathrm{mmol})$ and stirred at room temperature overnight. The reaction mixture was evaporated and the residue was purified by flash chromatography using hexane:ethyl acetate (92:8) as eluent to afford 29 as a white solid (78 $\mathrm{mg}, 53 \%)$; mp: $85-86{ }^{\circ} \mathrm{C} .{ }^{1} \mathrm{H} \mathrm{NMR}(400 \mathrm{MHz}$, $\left.\mathrm{CDCl}_{3}\right) \delta 8.14-8.09(\mathrm{~m}, 2 \mathrm{H}), 7.50-7.45(\mathrm{~m}, 3 \mathrm{H}), 7.38-7.28(\mathrm{~m}, 5 \mathrm{H}), 6.68-6.61(\mathrm{~m}, 1 \mathrm{H}), 5.03(\mathrm{~d}, J$ $=14.1 \mathrm{~Hz}, 1 \mathrm{H}), 4.93(\mathrm{~d}, J=14.1 \mathrm{~Hz}, 1 \mathrm{H}), 4.66(\mathrm{~d}, J=11.9 \mathrm{~Hz}, 1 \mathrm{H}), 4.60(\mathrm{~d}, J=11.9 \mathrm{~Hz}, 1 \mathrm{H})$, $3.68(\mathrm{~d}, J=10.1 \mathrm{~Hz}, 1 \mathrm{H}), 3.59(\mathrm{~d}, J=10.1 \mathrm{~Hz}, 1 \mathrm{H}), 2.93(\mathrm{~d}, J=17.0 \mathrm{~Hz}, 1 \mathrm{H}), 2.76(\mathrm{~d}, J=17.0$ $\mathrm{Hz}, 1 \mathrm{H}), 1.99$ (t, $J=6.2 \mathrm{~Hz}, 2 \mathrm{H}), 1.66-1.58(\mathrm{~m}, 1 \mathrm{H}), 1.58-1.47(\mathrm{~m}, 2 \mathrm{H}), 1.08-0.91(\mathrm{~m}, 4 \mathrm{H}), 0.82-$ $0.78(\mathrm{~m}, 12 \mathrm{H}) .{ }^{13} \mathrm{C} \mathrm{NMR}\left(101 \mathrm{MHz}, \mathrm{CDCl}_{3}\right) \delta 168.8,165.4,141.4,137.0,130.5,128.9,128.5$, $128.0,127.8,126.9,125.3,81.5,73.8,72.4,56.6,43.7,43.7,34.7,32.6,31.2,25.1,22.9,22.8$, 22.6, 22.5.HRMS (ESI) $m / z$ calcd. for $\mathrm{C}_{31} \mathrm{H}_{41} \mathrm{~N}_{4} \mathrm{O}_{3}(\mathrm{M}+\mathrm{H})^{+}:$517,3179, found 517,3182.

\section{(E)-5-(hydroxymethyl)-3-(3-isobutyl-5-methylhexylidene)-5-((5-phenyl-2H-tetrazol-2-}

\section{yl)methyl)dihydrofuran-2(3H)-one (6)}

Startingfrom 29 (50 mg, $0.097 \mathrm{mmol}$ ) and following general procedure B, 6wasobtained as awhitesolid (32 mg, 78\%); mp: 110-112 ${ }^{\circ} \mathrm{C} .{ }^{1} \mathrm{H}$ NMR (400 MHz, $\left.\mathrm{CDCl}_{3}\right) \delta$ 8.20-8.15 (m, 2H), 
7.51-7.49 (m, 3H), $6.70(\mathrm{~m}, 1 \mathrm{H}), 5.10-4.94(\mathrm{AB} \mathrm{m}, 2 \mathrm{H}), 3.79-3.76(\mathrm{~m}, 2 \mathrm{H}), 2.94(\mathrm{~d}, J=17.2$ $\mathrm{Hz}, 1 \mathrm{H}), 2.73(\mathrm{~d}, J=17.2 \mathrm{~Hz}, 1 \mathrm{H}), 2.57(\mathrm{t}, J=6.4 \mathrm{~Hz}, 1 \mathrm{H}), 2.03(\mathrm{t}, J=6.3 \mathrm{~Hz}, 2 \mathrm{H}), 1.67-1.60$ $(\mathrm{m}, 1 \mathrm{H}), 1.60-1.48(\mathrm{~m}, 2 \mathrm{H}), 1.11-0.93(\mathrm{~m}, 4 \mathrm{H}), 0.82(\mathrm{~d}, J=6.5 \mathrm{~Hz}, 12 \mathrm{H}) .{ }^{13} \mathrm{C} \mathrm{NMR}(101 \mathrm{MHz}$, $\left.\mathrm{CDCl}_{3}\right) \delta 168.8,165.6,142.2,130.6,128.9,126.9,126.8,125.3,82.5,65.7,56.0,43.8,43.8$ 34.8, 32.7, 30.4, 25.1, 22.9, 22.8, 22.6, 22.5.HRMS (ESI)m/zcalcd. for $\mathrm{C}_{24} \mathrm{H}_{35} \mathrm{~N}_{4} \mathrm{O}_{3}(\mathrm{M}+\mathrm{H})^{+}$: 427.2709, found 427.2733.

\section{Determination of in vitro binding affinities for PKC isozymes}

Recombinant human PKC $\alpha$ and PKCe isozymes were obtained from ThermoFisher Scientific (Waltham, MA). Compounds were assayed in vitro by competition for the binding of $\left[{ }^{3} \mathrm{H}\right] \mathrm{PDBu}$ (9 Ci/mmol; prepared as a custom synthesis by Quotient Bioresearch, Cardiff, United Kingdom). Porcine brain L- $\alpha$-phosphatidylserine (PS) was from Avanti Polar Lipids (Alabaster, AL). Immunoglobulin G was purchased from Sigma-Aldrich (St. Louis, MO). Nonradioactive phorbol 12,13-dibutyrate (PDBu) was purchased from LC Laboratories (Woburn, MA). Polyethylene glycol (PEG) 6000 was obtained from EMD Millipore Corporation (Billerica, MA).Briefly, the assay mixture had a final volume of $250 \mu \mathrm{l}$ and contained the following components: $50 \mathrm{mM}$ Tris-HCl, $\mathrm{pH} 7.4 ; 100 \mu \mathrm{g} / \mathrm{ml} \mathrm{L}-\alpha$-phosphatidylserine; $0.1 \mathrm{mM} \mathrm{Ca}^{2+}$ for PKC $\alpha$ assay and $1 \mathrm{mM}$ EGTA for PKC $\varepsilon$ assay; $5 \mathrm{mg} / \mathrm{ml}$ bovine immunoglobulin $\mathrm{G}$ and $0.003 \% \mathrm{Tx}-100,10 \mu \mathrm{M}$ of nonradioactive phorbol 12,13-dibutyrate (PDBu), 2 nM of $\left[{ }^{3} \mathrm{H}\right] \mathrm{PDBu}$ and increasing concentrations of the competing ligand. The assay tubes were incubated at $37^{\circ} \mathrm{C}$ for 5 minutes, and then chilled on ice for 10 minutes, after which $200 \mu 1$ of $35 \%$ polyethylene glycol (PEG) was added. The tubes were vortexed and chilled for an additional 10 minutes. The tubes were then centrifuged at $12,200 \mathrm{rpm}$ for 15 minutes at $4^{\circ} \mathrm{C}$. A $200 \mu \mathrm{l}$ aliquot of each supernatant was transferred to a scintillation vial for the determination of the free concentration of $\left[{ }^{3} \mathrm{H}\right] \mathrm{PDBu}$. 
The assay pellets were dried, cut off, and placed in a separate scintillation vial for the determination of bound $\left[{ }^{3} \mathrm{H}\right] \mathrm{PDBu}$. The supernatant and pellet vials were immersed in $3 \mathrm{ml}$ of scintillation cocktail (CytoScintEcoSafe, MP Biomedicals, Santa Ana, CA). In each experiment, triplicate measurements at each concentration of ligand were performed. MS Excel was used to process data and graphing was done using GraphPad Prism software (GraphPad Software, Inc., San Diego, CA). Final concentrations for both PKC isozymes assays (fixed): $10 \mu \mathrm{M}$ cold PDBu (nonspecific), $2 \mathrm{nM}\left[{ }^{3} \mathrm{H}\right] \mathrm{PDBu}, 20 \mathrm{ng} /$ tube enzyme, $100 \mu \mathrm{g} / \mathrm{ml} \mathrm{L}-\alpha$-phosphatidylserine (porcine brain).In each experiment, at least triplicate measurements at each concentration of ligand were performed. Ki values were calculated from ID $_{50}$ values determined from the competition curves. MS Excel was used to process data and graphing was done using GraphPad Prism software (GraphPad Software, Inc., San Diego, CA).

\section{Translocation of GFP-fused PKCs}

Experiments were carried out essentially as previously described. ${ }^{16}$ Briefly, HeLa cells (5 × $10^{4}$ ) were transfected with $1 \mu \mathrm{g}$ of either pEGFP-N1-PKC $\alpha$ or pEGFP-N1-PKCeusing Lipofectamine 3000 and plated on coverslides in 24-well plates. After $24 \mathrm{~h}$, cells were serumstarved for $24 \mathrm{~h}$ and then stimulated with the different DAG-lactones or PMA for $30 \mathrm{~min}$. Cells were then fixed in methanol, mounted on a glass slide, and visualized with a Nikon TE2000-U fluorescence microscope. Translocation was quantitated using ImageJ. A line was traced across the cytoplasm of individual cells (5-10/group), and the signal intensities and profiles were obtained using the Plot profile tool of the program.

\section{Western blotting}


A549 cells were harvested in lysis buffer containing $50 \mathrm{mM}$ Tris- $\mathrm{HCl}, \mathrm{pH} 6.8,10 \%$ glycerol and $2 \% \beta$-mercaptoethanol, and lysates were subjected to SDS-PAGE. After transferring to polyvinylidene difluoride membranes (Millipore Corp., Burlington, MA) and blockade for $1 \mathrm{~h}$ with 5\% milk in TBS and 0.1\% Tween 20, membranes were incubated overnight with either anti$\operatorname{PKC} \varepsilon(1: 1,000$ dilution, Cell Signaling Technology, Danvers, MA) or $\beta$-actin $(1: 50,0000$, SigmaAldrich, St. Louis, MO) antibodies. After extensive washing, membranes were incubated for $1 \mathrm{~h}$ with either anti-mouse (1:1,000 dilution) or anti-rabbit (1:3,000 dilution) secondary antibodies conjugated to horseradish peroxidase (Bio-Rad, Hercules, CA). Bands were visualized and subjected to densitometric analysis using an Odyssey Fc system (LI-COR Biosciences, Lincoln, $\mathrm{NE})$.

\section{Quantitative PCR (Q-PCR)}

Total RNA from cultured cells were extracted using the RNeasy kit as directed by the manufacturer (Qiagen, Valencia, CA). One $\mu \mathrm{g}$ of mRNA template was added to the reversetranscription master mix (Taq-Man Reverse Transcription kit, Applied Biosystems). The cDNA samples were then diluted with $90 \mu \mathrm{l}$ of RNase-free water and stored at $-20^{\circ} \mathrm{C}$.Q-PCR primers for PKC $\varepsilon$ and UBC (housekeeping gene for normalization) were purchased from Applied Biosystems. PCR amplifications were performed using an ABI PRISM 7300 Detection System in a total volume of $20 \mu \mathrm{l}$ containing Taqman Universal PCR Master Mix (Applied Biosystems). PCR product formation was continuously monitored using the Sequence Detection System software version 1.7 (Applied Biosystems).

\section{Phalloidin staining for analysis of cell ruffle formation}


A549 lung cancer cells growing on glass coverslides at low confluence were serum-starved for $24 \mathrm{~h}$ and stimulated with the different compounds at the concentrations indicated. Following fixation with $4 \%$ formaldehyde, F-actin was stained with phalloidin-rhodamine, and nuclei were counterstained with DAPI. Slides were visualized by fluorescence microscopy, and five random fields were scored for ruffle formation. Ruffle area was measured by thresholding for signal intensity using ImageJ.

\section{RNAi silencing}

A549 cells were transfected with validated siRNA duplexes for PKC $\varepsilon$ or a non-target control (NTC) siRNA duplex (Dharmacon) using Lipofectamine RNAiMAX (Invitrogen), as previously described. ${ }^{16}$ siRNAi's for PKC $\varepsilon$ were as follows: J-004653-06 ( $\left.\varepsilon 1\right)$ and J-004653-08 ( $\left.\varepsilon 2\right)$. Experiments were carried out $48 \mathrm{~h}$ after transfection.

\section{Statistical analysis}

We used GraphPad Prism software built-in analysis tools for ANOVA. A $p$ value $<0.05$ was considered statistically significant.

\section{ASSOCIATED CONTENT}

Supporting Information. The following files are available free of charge.

Data for ${ }^{1} \mathrm{H}$ and ${ }^{13} \mathrm{C}$ NMR Spectra of the title compounds (PDF)

Molecular formula strings (CSV) 


\section{AUTHOR INFORMATION}

\section{Corresponding Authors}

* María Julieta Comin - Instituto Nacional de Tecnología Industrial - San Martín, Buenos Aires, Argentina; phone: +54 911 44307859. Email: jcomin@inti.gob.ar

* Marcelo Kazanietz † Department of Systems Pharmacology and Translational Therapeutics, Perelman School of Medicine, University of Pennsylvania, Philadelphia, USA; phone: +1 215898-025. Email: marcelog@pennmedicine.upenn.edu

\section{ACKNOWLEDGMENTS}

This work was partly supported by ANPCyT (PICT-201-0362 to MJC and PICT-2018-N 01036), CONICET (PIP2014-2016 GI to MJC), The National Institute of Industrial Technology (INTI), as well as by National Institutes of Health grants ES026023, CA189765 and CA196232 (to MGK). This work was also supported in part with Federal funds from the Frederick National Laboratory for Cancer Research, National Institutes of Health, under contract HHSN261200800001E. The content of this publication does not necessarily reflect the views or policies of the Department of Health and Human Services, nor does mention of trade names, commercial products or organizations imply endorsement by the US Government.

\footnotetext{
ABBREVIATIONS

CAN, ceric ammonium nitrate; DAG, diacylglycerol; DBU, 1,8-diazabicyclo[5.4.0]undec-7-ene; DIAD, diisopropyl azodicarboxylate; DMAP, 4-dimethylaminopyridine; DMF,
} 
dimethylformamide; GEFs, guanine nucleotide exchange factors; LiHMDS, lithium

hexamethyldisilazide; mp, melting point; MRCKs, myotonic dystrophy kinase-related Cdc42-

binding kinases (MRCKs); PDBu, [20-3H]phorbol 12,13-dibutyrate; PKC, protein kinase C;

PKD, protein kinase D; PMP, p-methoxyphenyl; pyr, pyridine; RasGRP, Ras guanine

nucleotide-releasing protein; TBAF, tetra-n-butylammonium fluoride; TBDPS, tert-

butyldiphenylsilyl; $t$-BuOH, tert-butylalcohol; THF, tetrahydrofuran.

\section{REFERENCES}

(1) Cooke, M.; Magimaidas, A.; Casado-Medrano, V.; Kazanietz, M. G. Protein Kinase C in Cancer: The Top Five Unanswered Questions. Mol. Carcinogénesis 2017, 56 (6), 15311542. https://doi.org/10.1002/mc.22617.

(2) Mochly-Rosen, D.; Das, K.; Grimes, K. V. Protein Kinase C, an Elusive Therapeutic Target? Nat. Rev. Drug Discov. 2012, 11, 937.

(3) Singh, R. M.; Cummings, E.; Pantos, C.; Singh, J. Protein Kinase C and Cardiac Dysfunction: A Review. Heart Fail. Rev. 2017, 22 (6), 843-859. https://doi.org/10.1007/s10741-017-9634-3.

(4) Kaleli, H. N.; Ozer, E.; Kaya, V. O.; Kutlu, O. Protein Kinase C Isozymes and Autophagy during Neurodegenerative Disease Progression. Cells 2020, 9 (3), 553. https://doi.org/10.3390/cells9030553.

(5) Kolczynska, K.; Loza-Valdes, A.; Hawro, I.; Sumara, G. Diacylglycerol-Evoked Activation of PKC and PKD Isoforms in Regulation of Glucose and Lipid Metabolism: A Review. Lipids Health Dis. 2020, 19, 1-15. https://doi.org/10.1186/s12944-020-01286-8.

(6) Das, J.; Rahman, G. M. C1 Domains: Structure and Ligand-Binding Properties. Chem. Rev. 2014, 114 (24), 12108-12131. https://doi.org/10.1021/cr300481j.

(7) Blumberg, P. M.; Kedei, N.; Lewin, N. E.; Yang, D.; Czifra, G.; Pu, Y.; Peach, M. L.; Marquez, V. E. Wealth of Opportunity-the C1 Domain as a Target for Drug Development. Curr. Drug Targets 2008, 9 (8), 641.

(8) Mellor, H.; Parker, P. J. The Extended Protein Kinase C Superfamily. Biochem. J. 1998, 332 (2), 281-292. https://doi.org/10.1042/bj3320281. 
(9) Griner, E. M.; Kazanietz, M. G. Protein Kinase C and Other Diacylglycerol Effectors in Cancer. Nat. Rev. Cancer 2007, 7 (4), 281-294. https://doi.org/10.1038/nrc2110.

(10) Marquez, V. E.; Blumberg, P. M. Synthetic Diacylglycerols (DAG) and DAG-Lactones as Activators of Protein Kinase C (PK-C). Acc. Chem. Res. 2003, 36 (6), 434-443. https://doi.org/10.1021/ar020124b.

(11) El Kazzouli, S.; Lewin, N. E.; Blumberg, P. M.; Marquez, V. E. Conformationally Constrained Analogues of Diacylglycerol. 30. An Investigation of Diacylglycerol-Lactones Containing Heteroaryl Groups Reveals Compounds with High Selectivity for Ras Guanyl Nucleotide-Releasing Proteins. J. Med. Chem. 2008, 51 (17), 5371-5386.

(12) Duan, D.; Sigano, D. M.; Kelley, J. A.; Lai, C. C.; Lewin, N. E.; Kedei, N.; Peach, M. L.; Lee, J.; Abeyweera, T. P.; Rotenberg, S. A.; Kim, H.; Young, H. K.; El Kazzouli, S.; Chung, J. U.; Young, H. A.; Young, M. R.; Baker, A.; Colburn, N. H.; Haimovitz-Friedman, A.; Truman, J. P.; Parrish, D. A.; Deschamps, J. R.; Perry, N. A.; Surawski, R. J.; Blumberg, P. M.; Marquez, V. E. Conformationally Constrained Analogues of Diacylglycerol. 29. Cells Sort Diacylglycerol-Lactone Chemical Zip Codes to Produce Diverse and Selective Biological Activities. J. Med. Chem. 2008, 51 (17), 5198-5220. https://doi.org/10.1021/jm8001907.

(13) Nacro, K.; Bienfait, B.; Lee, J.; Han, K. C.; Kang, J. H.; Benzaria, S.; Lewin, N. E.; Bhattacharyya, D. K.; Blumberg, P. M.; Marquez, V. E. Conformationally Constrained Analogues of Diacylglycerol (DAG). 16. How Much Structural Complexity Is Necessary for Recognition and High Binding Affinity to Protein Kinase C? J. Med. Chem. 2000, 43 (5), 921-944. https://doi.org/10.1021/jm9904607.

(14) Zhang, G.; Kazanietz, M. G.; Blumberg, P. M.; Hurley, J. H. Crystal Structure of the Cys2 Activator-Binding Domain of Protein Kinase C Delta in Complex with Phorbol Ester. Cell 1995, 81 (6), 917-924.

(15) Pu, Y.; Perry, N. A.; Yang, D.; Lewin, N. E.; Kedei, N.; Braun, D. C.; Choi, S. H.; Blumberg, P. M.; Garfield, S. H.; Stone, J. C.; Duan, D.; Marquez, V. E. A Novel Diacylglycerol-Lactone Shows Marked Selectivity in Vitro among C1 Domains of Protein Kinase C (PKC) Isoforms $\alpha$ and $\delta$ as Well as Selectivity for RasGRP Compared with PKC $\alpha$. J. Biol. Chem. 2005, 280 (29), 27329-27338. https://doi.org/10.1074/jbc.M414132200.

(16) Cooke, M.; Zhou, X.; Casado-Medrano, V.; Lopez-Haber, C.; Baker, M. J.; Garg, R.; Ann, J.; Lee, J.; Blumberg, P. M.; Kazanietz, M. G. Characterization of AJH-836, a DAGLactone with Selectivity for Novel PKC Isozymes. J. Biol. Chem. 2018, 293 (22), 83308341. https://doi.org/10.1074/jbc.RA117.000235.

(17) Cooke, M.; Casado-Medrano, V.; Ann, J.; Lee, J.; Blumberg, P. M.; Abba, M. C.; Kazanietz, M. G. Differential Regulation of Gene Expression in Lung Cancer Cells by DiacyglycerolLactones and a Phorbol Ester Via Selective Activation of Protein Kinase C Isozymes. Sci. Rep. 2019, 9 (1), 1-15. https://doi.org/10.1038/s41598-019-42581-4. 
(18) Lee, J.; Han, K.-C.; Kang, J.-H.; Pearce, L.L.; Lewin, N. E.; Yan, S.; Benzaria, S.; Nicklaus, M. C.; Blumberg, P. M.; Marquez, V. E. Conformationally Constrained Analogues of Diacylglycerol. 18. The Incorporation of a Hydroxamate Moiety into DiacylglycerolLactones Reduces Lipophilicity and Helps Discriminate between Sn-1 and Sn-2 Binding Modes to Protein Kinase C (PK-C). Implications . J. Med. Chem. 2001, 44 (25), 4309-4312. https://doi.org/10.1021/jm0103965.

(19) Kang, J.-H.; Chung, H.-E.; Kim, S. Y.; Kim, Y.; Lee, J.; Lewin, N. E.; Pearce, L. V; Blumberg, P. M.; Marquez, V. E. Conformationally Constrained Analogues of Diacylglycerol (DAG). Effect on Protein Kinase C (PK-C) Binding by the Isosteric Replacement of Sn-1 and Sn-2 Esters in DAG-Lactones. Bioorg. Med. Chem. 2003, 11 (12), 2529-2539. https://doi.org/10.1016/S0968-0896(03)00156-1.

(20) Lenzl, S. M.; Meierl, E.; Pedersenl, H.; Frederiksenl, K.; Bogeso, K.; Krogsgaard-Larsen, P. Muscarinic Agonists. Syntheses and Structure-Activity Relationships of Bicyclic Isoxazole Ester Bioisosteres of Norarecoline. Eur. J. Med. Chem. 1995, 30, 263-270.

(21) Meanwell, N. A. Synopsis of Some Recent Tactical Application of Bioisosteres. J. Med. Chem. 2011, 54, 2529-2591.

(22) Bonandi, E.; Christodoulou, M. S.; Fumagalli, G.; Perdicchia, D.; Rastelli, G.; Passarella, D. The 1,2,3-Triazole Ring as a Bioisostere in Medicinal Chemistry. Drug Discov. Today 2017, 22 (10), 1572-1581. https://doi.org/10.1016/j.drudis.2017.05.014.

(23) Neochoritis, C. G.; Zhao, T.; Dömling, A. Tetrazoles via Multicomponent Reactions. Chem. Rev. 2019, 119, 1970-2042. https://doi.org/10.1021/acs.chemrev.8b00564.

(24) Evgen, R.; Popova, E. A. Medicinal Chemistry of Tetrazoles Medicinal Chemistry of Tetrazoles. Russ. Chem. Bull. Int. Ed. 2013, 61 (4), 768-780. https://doi.org/10.1007/s11172-012-0108-4.

(25) Nobeli, I.; Price, S. L.; Lommerse, J. P. M.; Taylor, R. Hydrogen Bonding Properties of Oxygen and Nitrogen Acceptors in Aromatic Heterocycles. J. Comput. Chem. 1997, 18 (16), 2060-2074.

(26) Tamamura, H.; Sigano, D. M.; Lewin, N. E.; Blumberg, P. M.; Marquez, V. E. Conformationally Constrained Analogues of Diacylglycerol. 20. The Search for an Elusive Binding Site on Protein Kinase C through Relocation of the Carbonyl Pharmacophore Along the Sn-1 Side Chain of 1,2-Diacylglycerol Lactones. J. Med. Chem. 2004, 47 (3), 644-655.

(27) Elhalem, E.; Donadío, L. G.; Zhou, X.; Lewin, N. E.; Garcia, L. C.; Lai, C. C.; Kelley, J. A.; Peach, M. L.; Blumberg, P. M.; Comin, M. J. Exploring the Influence of Indololactone Structure on Selectivity for Binding to the C1 Domains of PKC $\alpha, \mathrm{PKC} \varepsilon$, and RasGRP. Bioorganic Med. Chem. 2017, $25 \quad$ (12), 2971-2980. https://doi.org/10.1016/j.bmc.2017.03.022. 
(28) Sørensen, U.; Falch, E.; Krogsgaard-larsen, P. A Novel Route to 5-Substituted 3Isoxazolols. Cyclization of N , O-DiBoc $\beta$-Keto Hydroxamic Acids Synthesized via Acyl Meldrum's Acids. J. Org. Chem. 2000, 65 (10), 1003-1007.

(29) Totobenazara, J.; Burke, A. J. New Click-Chemistry Methods for 1,2,3-Triazoles Synthesis: Recent Advances and Applications. Tetrahedron Lett. 2015, 56 (22), 2853-2859. https://doi.org/10.1016/j.tetlet.2015.03.136.

(30) Zhu, R.; Buchwald, S. L. Versatile Enantioselective Synthesis of Functionalized Lactones via Copper-Catalyzed Radical Oxyfunctionalization of Alkenes. J. Am. Chem. Soc. 2015, 137 (25), 8069-8077. https://doi.org/10.1021/jacs.5b04821.

(31) Rostovtsev, V. V; Green, L. G.; Fokin, V. V; Sharpless, K. B. A Stepwise Huisgen Cycloaddition Process : Copper (I) -Catalyzed Regioselective "Ligation" of Azides and Terminal Alkynes. Angew. Chemie 2002, 114 (14), 2708-2711.

(32) Lee, J. Design and Synthesis of Bioisosteres of Ultrapotent Protein Kinase C (PKC) Ligand, 5-Acetoxymethyl-5-Hydroxymethyl-3-Alkylidene Tetrahydro-2-Furanone. Arch. Pharm. Res. 1998, 21 (4), 452-457. https://doi.org/10.1007/BF02974642.

(33) Choi, Y.; Kang, J.; Lewin, N. E.; Blumberg, P. M.; Lee, J.; Marquez, V. E. Protein Kinase C Binding Affinity of Diacylglycerol Lactones Bearing an N-Hydroxylamide Side Chain. J. Med. Chem. 2003, 46, 2790-2793.

(34) Choi, Y.; George, C.; Comin, M. J.; Barchi, J. J.; Kim, H. S.; Jacobson, K. A.; Balzarini, J.; Mitsuya, H.; Boyer, P. L.; Hughes, X. S. H.; Marquez, V. E. A Conformationally Locked Analogue of the Anti-HIV Agent Stavudine. An Important Correlation between Pseudorotation and Maximum Amplitude. J. Med. Chem. 2003, 46, 3292-3299. https://doi.org/10.1021/jm030116g.

(35) Frølund, B.; Jørgensen, A. T.; Tagmose, L.; Stensbøl, T. B.; Vestergaard, H. T.; Engblom, C.; Kristiansen, U.; Sanchez, C.; Krogsgaard-larsen, P.; Liljefors, T. Novel Class of Potent 4-Arylalkyl Substituted 3-Isoxazolol GABA A Antagonists: Synthesis , Pharmacology , and Molecular Modeling. J. Med. Chem. 2002, 45, 2454-2468.

(36) Akhlaghinia, B.; Rezazadeh, S. A Novel Approach for the Synthesis of 5-Substituted-1. J. Brazilian Chem. Soc. 2012, 23 (12), 2197-2203.

(37) Malolanarasimhan, K.; Kedei, N.; Sigano, D. M.; Kelley, J. A.; Lai, C. C.; Lewin, N. E.; Surawski, R. J.; Pavlyukovets, V. A.; Garfield, S. H.; Wincovitch, S.; Blumberg, P. M.; Marquez, V. E. Conformationally Constrained Analogues of Diacylglycerol (DAG). 27. Modulation of Membrane Translocation of Protein Kinase C (PKC) Isozymes $\alpha$ and $\delta$ by Diacylglycerol Lactones (DAG-Lactones) Containing Rigid-Rod Acyl Groups. J. Med. Chem. 2007, 50 (5), 962-978. https://doi.org/10.1021/jm061289j.

(38) Protocols, P. K. C. [3H]-Phorbol 12,13-Dibutyrate Binding Assay for Protein Kinase C and Related Proteins. Protein Kinase C Protocols. Methods in Molecular Biology; Humana Press: Totowa, New Jersey, 2003. 
(39) Kazanietz, M. G.; Krausz, K. W.; Blumberg, P. M. Differential Irreversible Insertion of Protein Kinase $\mathrm{C}$ into Phospholipid Vesicles by Phorbol Esters and Related Activators. $J$. Biol. Chem. 1992, 267 (29), 20878-20886.

(40) Szallasi, Z.; Smith, C. B.; Pettit, G. R.; Blumberg, P. M. Differential Regulation of Protein Kinase C Isozymes by Bryostatin 1 and Phorbol 12-Myristate 13-Acetate in NIH 3 T3 Fibroblasts. J. Biol. Chem. 1994, 269 (3), 2118-2124.

(41) Ann, J.; Yoon, S.; Baek, J.; Kim, D. H.; Lewin, N. E.; Hill, C. S.; Blumberg, P. M.; Lee, J. Design and Synthesis of Protein Kinase C Epsilon Selective Diacylglycerol Lactones (DAG-Lactones). Eur. J. Med. Chem. 2015, 90, 332-341. https://doi.org/10.1016/j.ejmech.2014.11.025.

(42) Garg, R.; Blando, J. M.; Perez, C. J.; Abba, M. C.; Benavides, F.; Kazanietz, M. G. Protein Kinase C Epsilon Cooperates with PTEN Loss for Prostate Tumorigenesis through the CXCL13-CXCR5 Pathway. Cell Rep. 2017, 19 (2), 375-388. https://doi.org/10.1016/j.celrep.2017.03.042.

(43) Garg, R.; Blando, J. M.; Perez, C. J.; Lal, P.; Feldman, M. D.; Smyth, E. M.; Ricciotti, E.; Grosser, T.; Benavides, F.; Kazanietz, M. G. COX-2 Mediates pro-Tumorigenic Effects of PKCe in Prostate Cancer. Oncogene 2018, 37 (34), 4735-4749. https://doi.org/10.1038/s41388-018-0318-9.

(44) http://zinc15.docking.org/patterns/home/.

(45) Jones, G.; Willett, P.; Glen, R. C.; Leach, A. R.; Taylor, R. Development and Validation of a Genetic Algorithm for Flexible Docking. J. Mol. Biol. 1997, 267 (3), 727-748. https://doi.org/http://dx.doi.org/10.1006/jmbi.1996.0897.

(46) Verdonk, M. L.; Cole, J. C.; Hartshorn, M. J.; Murray, C. W.; Taylor, R. D. Improved Protein - Ligand Docking Using GOLD. PROTEINS Struct. Funct. Genet.2003, 52, 609_ 623.

(47) MacroModel, Version 10.1, Schrödinger Inc., New York, NY, 2013. 